\title{
Analisis Kinerja Keuangan Koperasi Unit Desa Maju Bersama Desa Kencana Mulia Kecamatan Rambang
}

\author{
Rani Andani ${ }^{1}$, Reva Maria Valianti ${ }^{2}$ \\ ${ }^{1}$ Fakultas Ekonomi Universitas PGRI Palembang \\ ${ }^{2}$ Fakultas Ekonomi Universitas PGRI Palembang, revavalianti@univpgri-palembang.ac.id
}

\begin{abstract}
This study aims to determine how the analysis of the use of working capital in increasing profit at PT. Handjaya Mandala Sampoerna Tbk, which is listed on the Indonesia Stock Exchange. The analytical method used is descriptive and comparative analysis method using working capital adequacy ratio which consists of three ratios, namely the ratio of total assets to current ratio and working capital turnover. The use of working capital in increasing the annual report profit from PT. Handjaya Mandala Sampoerna Tbk which is listed on the Indonesia Stock Exchange for the period 2015 s / d 2017. The results of this study indicate that the use of working capital from 2015 to 2017 has increased every year. Report on the source and use of working capital of PT. Handjaya Mandala Sampoerna Tbk has a good source of working capital because in 2015 to 2017 the source of working capital was greater than the use of working capital. The role of using working capital in increasing profits shows that the level of effectiveness and efficiency in maintaining the company's financial turnover can run well. Analysis of the evaluation of the adequacy of working capital levels of changes in liquidity. Total assets showed 2,926, current ratio showed 3,616 and working capital turnover showed 2,837.
\end{abstract}

Keywords: Source, Use, Working Capital Adequacy Evaluation.

\section{ABSTRAK}

Penelitian ini bertujuan untuk mengetahui tingkat kesehatan Koperasi Unit Desa Maju Bersama tahun 2016-2018 berdasarkan Peraturan Deputi Bidang Pengawasan Kementerian Koperasi dan UKM Nomor: 06/Per/Dep.6/IV/2016. Jenis penelitian deskriptif kualitatif.Subjek penelitian ini adalah Koperasi Unit Desa Maju BersamaDesa Kencana Mulia dan yang menjadi objek dalam penelitian ini adalah tingkat kesehatannya.populasi dan sampel dalam penelitian ini berupa laporan laba/rugi dan neraca dalam buku Rapat Anggota Tahunan (RAT). Pengumpulan data dalam penelitian ini menggunakan metode wawancara dan dokumentasi. Teknik analisis data yang digunakan dalam penelitian ini adalah analisis deskriptif kualitatif. Hasil penelitian ini menunjukkan bahwa secara keseluruhan tingkat kesehatan Koperasi Unit Desa Maju Bersama tahun 2016-2018 berada dalam kategori kurang sehat dengan mendapatkan rata-rata skor sebesar 55,89. Aspek permodalan mendapatkan skor 80,00 (sehat); aspek kualitas aktiva produktif mendapatkan skor 58,32 (kurang sehat); aspek efisiensi mendapatkan skor 60,00 (cukup sehat); dan aspek likuiditas mendapatkan skor 25 (tidak sehat);

Kata Kunci: Kinerja Keuangan Koperasi

\section{A. PENDAHULUAN}

Indonesia sebagai salah satu negara yang berkembang dituntut untuk senantiasa meningkatkan pertumbuhan ekonomi masyarakatnya melalui pembinaan pilar ekonomi yang di anggap mampu menopang dan meningkatkan kesejahteraan masyarakat secara adil dan merata. Pembangunan ekonomi di Indonesia dilakukan oleh tiga pelaku ekonomi, yaitu Badan Usaha Milik Negara (BUMN), Badan Usaha 
Milik Swasta (BUMS), dan Koperasi.Ketiga pelaku tersebut merupakan pilar ekonomi yang dianggap mampu untuk mewujudkan kesejahteraan masyarakat Indonesia adalah Koperasi.

Koperasi memiliki arti penting dalam membangun perekonomian nasional, seperti yang tertuang dalam pasal 33 Ayat 1 Undang-Undang 1945 yang berbunyi "Perekonomian disusun sebagai usaha bersama atas asas kekeluargaan".Badan usaha yang paling sesuai dengan pasal tersebut adalah Koperasi. Koperasi merupakan satu-satunya bentuk badan usaha yang paling sesuai dengan semangat dan jiwa gontong royong bangsa Indonesia, oleh karena itu koperasi mendapat misi untuk berperan nyata dalam menyusun perekonomian nasional yang berdasarkan atas asas kekeluargaan dan demokrasi ekonomi dengan mengutamakan kesejahteraan masyarakat bukan kesejahteraan seseorang atau pribadi.

Menurut Hatta dalam Tanjung (2016:68), menjelaskan bahwa Koperasi adalah usaha bersama untuk memperbaiki nasib penghidupan ekonomi berdasarkan asas tolong menolong. Semangat tolong menolong tersebut didorong oleh adanya keinginan memberikan jasa kepada kawan berdasarkan "seorang buat semua, dan semua buat seorang"

Menurut Undang-Undang Republik Indonesia nomor 25 tahun 1992.Dalam UU tersebut menjelaskan bahwa Koperasi adalah badan usaha yang beranggotakan orang-orang atau badan hukum koperasi dengan melandaskan kegiatannya berdasarkan prinsip koperasi sekaligus sebagai gerakan ekonomi rakyat yang berdasar atas asas kekeluargaan.

Sesuai dengan beberapa definisi koperasi diatas sebagai salah satu badan usaha yang berkaitan langsung dengan masyarakat berupa anggota maka untuk meningkatkan usaha dan kesejahteraan anggota, maka koperasi dapat menghimpun dana dan menyalurkan dana dari dan untuk anggota, dan calon anggota, yang perlu dikelola secara profesional dalam mengelola kinerja keuangan Koperasi sesuai dengan prinsip kehati-hatian, sehingga dapat meningkatkan kepercayaan dan memberikan manfaat yang sebesar-besarnya kepada anggota dan masyarakat disekitarnya. Usaha yang dijalankan oleh koperasi dapat berupa usaha simpan pinjam dan pertokoan yang menjual barang-barang konsumsi.

Kinerja keuangan koperasi adalah hasil prestasi kerja dari koperasi pada periode tertentu dalam usaha mencapai daya guna dan hasil guna dalam pengembangan kegiatan usaha setinggi-tingginya yang dapat dilihat melalui kepemilikan modal sendiri dan data keuangan koperasi yang terdiri dari neraca dan laporan laba-rugi. Koperasi dapat menangani perencanaan, pengendalian serta mampu menganalisis kinerja keuangan yang telah mampu dicapai saat ini sebagai acuan untuk penetapan laporan keuangan tahun mendatang.

Laporan keuangan koperasi dibuat untuk menyediakan informasi atas aktivitasaktivitas koperasi yang diberikan kepada pihak-pihak yang berkepentingan melalui rapat anggota tahunan koperasi. Analisis kinerja keuangan koperasi, dilakukan dengan menyusun laporan keuangan (Financial statement) yang terdiri dari Laporan Neraca, Perhitungan Hasil Usaha, Laporan Arus Kas, Laporan Laba-Rugi, Laporan Promosi Ekonomi Anggota, dan Catatan atas Laporan Keuangan.

Laporan keuangan mempunyai peranan penting bagi setiap entitas sebagai acuan penetapan kebijakan keuangan.Sebagaimana Koperasi Unit Desa Maju Bersama Desa Kencana Mulia dalam mencapai kinerja keuangan koperasi yang baik, maka diperlukan penetapan kebijakan keuangan yang tepat.Hal ini dilakukan dengan memandang perekonomian yang mengalami kondisi sulit untuk berkembang. 
Kinerja keuangan koperasi pada posisi seimbang atau bertahan dapat dikatan sudah bagus, apalagi hingga bisa melebihi ketentuan standar Departemen Koperasi, yang mana akan membawa koperasi ke arah tercapainya tujuan untuk mensejahterahkan anggotanya dengan meningkatkan Sisa Hasil Usaha (SHU).

Laporan keuangan tersebut akan lebih berarti bagi pihak-pihak yang berkepentingan apabila data tersebut dibandingkan untuk dua periode atau lebih dan kemudian dianalisis. Dengan mengadakan analisis terhadap Neraca, Laporan Laba Rugi, dan Laporan Perhitungan Hasil Usaha pada koperasi akan dapat diketahui komponen mana yang mengalami suatu permasalahan, sehingga dapat diketahui cara memecahkan masalah yang timbul untuk mencapai kemajuan di masa yang akan datang.

Analisis keuangan merupakan suatu proses yang bertujuan menentukan ciri-ciri yang penting tentang kinerja keuangan dan kegiatan koperasi berdasarkan data yang ada. Tujuan utama analisis kinerja keuangan untuk memperoleh pandangan yang lebih baik tentang masalah operasional dan keuangan yang dihadapi koperasi.Kinerja keuangan yang dinilai melalui rasio keuangan dapat memberi gambaran tentang sejarah koperasi dan posisi keuangan koperasi pada saat itu.

Salah Satu teknik dalam menganalisis Kesehatan KSP/USP Koperasi yaitu berdasarkan Peraturan Deputi Bidang Pengawasan Kemetrian Koperasi dan UKM Nomor 06/Per/Dep.6/IV/2016. Ruang lingkup penilaian tingkat kesehatan KSP/USP meliputi 7 aspek penilaian yaitu antara lain permodalan, kualitas aktiva produktif, manajemen, likuiditas, efisiensi, kemandirian dan pertumbumbahan, serta jati diri koperasi.Dalam melakukan penilaian kesehatan koperasi yaitu di awali dengan menghitung rasio-rasio dari masing-masing aspek. Hasil dari perhitungan rasio tersebut akan digunakan untuk menetapkan kriteria kesehatan koperasi. Hasil penjumlahan tersebut akanmenunjukkan kondisi tingkat kesehatan koperasi yang berada pada kondisi sehat, cukup sehat, dalam pengawasan, dan dalam pengawasan khusus.

Tingkat kesehatan koperasi ini bergantung pada pencapaian hasil dari penilaian masing-masing aspek.Jadi apabila hasil dari penilaian masing-masing aspek kesehatan koperasi itu baik maka koperasi tersebut dapat dikatakan sehat.Aspek permodalan merupakan hal yang penting dalam menjalankan usaha koperasi. Semakin baik permodalan tentunya akan mempermudah koperasi dalam mengembangkan usahanya.

Koperasi Unit Desa Maju Bersama merupakan Koperasi Serba Usaha yang telah lama berdiri di Desa Kencana Mulia.KUD Maju Bersama beranggotakan masyarakat berupa kelompok tani dan pengguna jasa WASERDA yang ada di Desa Kencana Mulia. Usaha yang dilakukan KUD Maju Bersama yaitu Usaha Produksi, Angkutan, Waserda, Pendidikan, dan usaha simpan pinjam. KUD Maju Bersama memberikan layanan yang relatif mudah bagi angggotanya. Namun demikian apakah layanan usaha koperasi tersebut sudah sesuai dengan standar mutu yang diharapkan oleh Kementrian Koperasi dan UKM atau belum.

Koperasi Unit Desa (KUD) Maju Bersama dalam segi permodalan mengalami kekurangan, sehingga KUD Maju Bersama belum maksimal mendanai aktiva/aset yang dimilikinya.Aset yang dimiliki itu merupakan alat untuk untuk mencapai penghasilan koperasi. Kualitas aktiva produktif yang dimiliki KUD Maju Bersana sangatlah tinggi, akan tetapi dengan tingginya aktiva produktif yang dimiliki KUD Maju Bersama belum maksimal dalam menghasilkan keuntungan. 


\section{B. KAJIAN TEORI}

\section{1) Analisis Kinerja Keuangan Koperasi}

Analisis Kinerja Keruangan pada koperasi sangat penting dilakukan, apalagi memingat koperasi perlu mengetahui kinerja keuangan sebagai pedoman dalam pengambilan keputusan terkait dengan masalah yang dihadapi. Salah satu cara mengukur kinerja keuangan pada koperasi adalah dengan menggunakan rasio keuangan. Dalam hal ini peneliti melakukan penilaian kinerja yang difokuskan pada Koperasi Unit Desa (KUD), sehingga pedoman yang digunakan adalah Perauran Menteri Koperasi dan Usaha Kecil Menengah Republik Indonesia Nomor 06/Per/Dep.6/IV/2016 tentang pedoman penilaian kesehatan Koperasi Simpan Pinjam (KSP) dan Unit Simpan Pinjam (USP) Koperasi adalah sebagai berikut:

\section{$>$ Permodalan}

Dalam hal ini aspek permodalan dinilai untuk mengetahui informasi mengenai kecukupan modal koperasi dalam mendukung kegiatan operasionalnya. Penilaian permodalan didasarkan pada 3 (tiga) rasio yaitu:

a) Rasio Modal Sendiri terhadap Total Aset

Rasio ini membandingkan antara modal sendiri dengan total aset koperasi.

Rasio ini dihitung dengan rumus sebagai berikut:

$$
\text { Rasio Modal Sendiri terhadap Total Aset }=\frac{\text { Modal Sendiri }}{\text { Total Aset }} \times 100 \%
$$

b) Rasio Modal Sendiri terhadap Pinjaman Diberikan yang Beresiko Penilaian rasio ini menggunakan perbandingan modal sendiri dengan pinjaman yang beresiko. Rasio inii dihitung dengan rumus sebagai berikut:

$$
\text { Rasio Modal Sendiri terhadap Pinjaman Diberikan yang Beresiko }
$$

$$
=\frac{\text { Modal sendiri }}{\text { Pinjaman diberikan yang beresiko }} \times 100 \%
$$

c) Rasio Kecukupan Modal Sendiri

Rasio ini membandingkan antara modal tertimbang deengan aktiva tertimbang menurut resiko (ATMR) dengan 100\%. Rasio ini dihitung dengan rumus sebagai berikut:

$$
\text { Rasio Kecukupan Modal Sendiri }=\frac{\text { Modal Sendiri Tertimbang }}{\text { ATMR }} \times 100 \%
$$

\section{$>\quad$ Kualitas Aktiva Produktif}

Aktiva produktif merupakan kekayaan koperasi yang mendatangkan penghasilan bagi koperasi yang bersangkutan. Adapun penilaian aspek kualitas aktiva produktif didasarkan pada 4 (empat) rasio, yaitu:

a) Rasio Volume Pinjaman Pada Anggota terhadap Total Volume Pinjaman Diberikan = $\frac{\text { Volume pinjaman pada anggota }}{\text { volume pinjaman }} \times 100 \%$

b) Rasio Risiko Pinjaman Bermasalah terhadap Pinjaman yang Diberikan Rasio ini dihitung dengan rumus sebagai berikut :

Rasio Risiko Pinjaman Bermasalah terhadap Pinjaman yang Diberikan

$$
=\frac{\text { Pinjaman Bermasalah }}{\text { Pinjaman Yang Diberikan }} \times 100 \%
$$

c) Hasil penjumlahan tersebut dibagi dengan pinjaman yang disalurkan.

$$
\mathrm{RPM}=\frac{(50 \% \times \mathrm{PKL})+(75 \% \times \mathrm{PDR})+(100 \% \times \mathrm{PM})}{\text { Pinjaman Yang Diberikan }}
$$


Rasio Cadangan Risiko terhadap Risiko Pinjaman Bermasalah

Rasio Cadangan Risiko terhadap Risiko Pinjaman Bermasalah

$$
=\frac{\text { Cadangan Resiko }}{\text { Pinjaman Bermasalah }} \times 100 \%
$$

Rasio Pinjaman yang Beresiko terhadap Pinjaman yang Diberikan.

Rasio Pinjaman yang Beresiko terhadap Pinjaman yang Diberikan= $\frac{\text { Pinjaman yang beresiko }}{\text { Pinjaman yang Diberikan }} \times 100 \%$

\section{$>$ Efisiensi}

Penilaian aspek ini bertujuan untuk menggambarkan sampai berapa saat KSP atau USP koperasi mampu memberikan pelayanan yang efisien kepada anggotanya dari penggunaan aset yang dimilikinya. Adapun penilaian aspek efisiensi didasarkan pada 3 (tiga) rasio, yaitu:

* Rasio beban operasi Anggota terhadap Pastisipasi Bruto

$$
=\frac{\text { Beban Operasi Anggota }}{\text { Partisipasi Bruto }} \times 100 \%
$$

* Rasio Beban Usaha terhadap SHU Kotor $=\frac{\text { Beban Usaha }}{\text { SHU Kotor }} \times 100 \%$

* Rasio Efisiensi Pelayanan $=\frac{\text { Biaya Karyawan }}{\text { Volume Pinjaman }} \times 100 \%$

\section{$>$ Likuiditas}

Dalam aspek ini yang ingin diketahui adalah kemampuan KSP dan atau USP Koperasi untuk memenuhi kewajiban jangka pendeknya. Adapun penilaian aspek likuiditas didasarkan pada 2 (dua) rasio, yaitu:

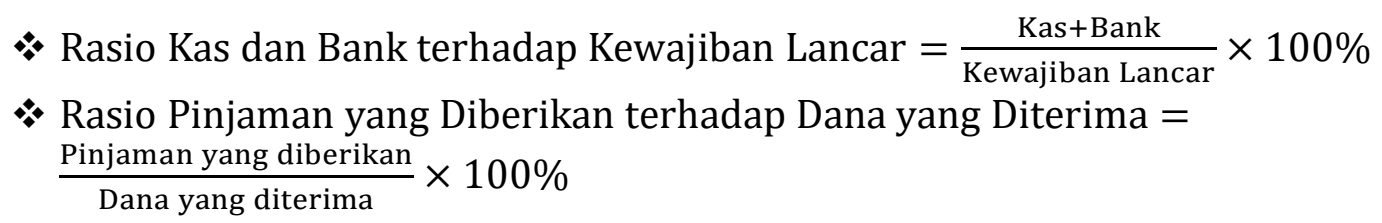

\section{2) Penetapan Kesehatan Keuangan Koperasi}

Dalam menentukan kinerja keuangan koperaasi maka perlu diperoleh skor keseluruhan dari perhitungan rasio-rasio dalam aspek dan komponen kesehatan koperasi yang dijalankan sebelumnya.Adapun bobot penilaian terhadap aspek dan komponen kesehatan koperasi tersebut ditetapkan sebagai berikut:

Tabel Bobot penilaian terhadap aspek dan komponen kesehatan koperasi

\begin{tabular}{|l|l|l|l|l|}
\hline No & Aspek & \multicolumn{1}{c|}{ Komponen } & \multicolumn{2}{c|}{$\begin{array}{c}\text { Bobot } \\
\text { penilaian }\end{array}$} \\
\hline 1 & Permodalan & & & 15 \\
\hline & & a. Rasio modal sendiri terhadap total aset & 6 & \\
\hline & $\begin{array}{l}\text { b. Rasio modal sendiri terhadap pinjaman } \\
\text { diberikan yang berisiko }\end{array}$ & 6 & \\
\hline 2 & Kualitas Aktiva & c. Rasio kecukupan modal sendiri & 3 & \\
\hline
\end{tabular}




\begin{tabular}{|c|c|c|c|c|}
\hline & Produktif & & & \\
\hline & & $\begin{array}{l}\text { a. Rasio pinjaman pada anggota terhadap } \\
\text { total volume pinjaman diberikan. }\end{array}$ & 10 & \\
\hline & & $\begin{array}{l}\text { b. Rasio risiko pinjaman bermasalah } \\
\text { terhadap pinjaman yang diberikan }\end{array}$ & 5 & \\
\hline & & $\begin{array}{l}\text { c. Rasio cadangan risiko terhadap risiko } \\
\text { pinjaman bermasalah }\end{array}$ & 5 & \\
\hline & & $\begin{array}{l}\text { d. Rasio pinjaman berisiko terhadap } \\
\text { pinjaman yang diberikan. }\end{array}$ & 5 & \\
\hline 3 & Efisiensi & & & 10 \\
\hline & & $\begin{array}{l}\text { a. Rasio beban operasi anggota terhadap } \\
\text { partisipasi bruto }\end{array}$ & 4 & \\
\hline & & b. Rasio beban usaha terhadap SHU kotor & 4 & \\
\hline & & c. Rasio efisiensi pelayanan & 2 & \\
\hline 4 & Likuiditas & & & 15 \\
\hline & & $\begin{array}{l}\text { a. Rasio kas dan bank terhadap kewajiban } \\
\text { lancar }\end{array}$ & 10 & \\
\hline & & $\begin{array}{l}\text { b. Rasio pinjaman yang diberikan terhadap } \\
\text { dana yang diterima }\end{array}$ & 5 & \\
\hline \multicolumn{3}{|c|}{ Jumlah } & & 65 \\
\hline
\end{tabular}

Sumber: Permen KUKM No.06/Per/Dep.6/IV/2016

Tabel Penetapan Predikat Tngkat Kesehatan Koperasi

\begin{tabular}{|c|c|}
\hline Skor & Predikat \\
\hline $80<X<100$ & Sehat \\
\hline $60<X<80$ & Cukup Sehat \\
\hline $40<X<60$ & Kurang Sehat \\
\hline $20<X<40$ & Tidak Sehat \\
\hline$<20$ & Sangat Tidak Sehat \\
\hline
\end{tabular}

Sumber: Permen KUKM No.06/Per/Dep.6/IV/2016

\section{Penelitian Terdahulu}

Dalam penelitian terdahulu yang dilakukan oleh Iman Syafudin (2017), Asih Wijayanti (2012), serta Tri Dewi Eidrias dan Devi Farah Azizah (2016).Terdapat perbedaan dan persamaan dengan penulis.Adapun perbedaan dan persaam tersebut penulis gambarkan dalam tabel sebagai berikut.

Tabel Penelitian Sebelumnya yang Relevan

\begin{tabular}{|l|l|l|l|l|l|}
\hline No & $\begin{array}{c}\text { Nama } \\
\text { Peneliti }\end{array}$ & \multicolumn{1}{|c|}{$\begin{array}{c}\text { Judul } \\
\text { Penelitian }\end{array}$} & \multicolumn{2}{|c|}{ Persamaan } & \multicolumn{2}{|c|}{ Perbedaan } & \multicolumn{2}{c|}{ Hasil } \\
\hline 1 & $\begin{array}{l}\text { Syaifudin } \\
2017\end{array}$ & $\begin{array}{l}\text { Analisis } \\
\text { Tingkat }\end{array}$ & $\begin{array}{l}\text { Veriabel yang } \\
\text { digunakan }\end{array}$ & $\begin{array}{l}\text { Subjek yaitu } \\
\text { penelitian }\end{array}$ & $\begin{array}{l}\text { Hasil penelitian } \\
\text { menunjukkan tingkat }\end{array}$ \\
\hline
\end{tabular}




\begin{tabular}{|c|c|c|c|c|c|}
\hline & & $\begin{array}{l}\text { Kesehatan } \\
\text { Koperasi } \\
\text { Simpan } \\
\text { Pinjam di } \\
\text { Kabupaten } \\
\text { Rembang } \\
\text { Tahun 2014- } \\
2015\end{array}$ & $\begin{array}{l}\text { meliputi } 4 \text { aspek } \\
\text { permodalan, } \\
\text { kualitas aktiva } \\
\text { produktif, efisiensi, } \\
\text { serta likuiditas }\end{array}$ & $\begin{array}{l}\text { mencakup } \\
\text { koperasi } \\
\text { sekabupaten } \\
\text { Rembang }\end{array}$ & \begin{tabular}{lr} 
kesehatan Koperasi & \multicolumn{1}{r}{ Kimpan Pinjam di } \\
Kabupaten Rembang \\
ditinjau dari & aspek \\
permodalan, & aspek \\
kualitas & aktiva \\
produktif, & aspek \\
efisiensi, & aspek \\
likuiditas, & aspek \\
kemandirian & dan \\
pertumbuhan, & serta \\
aspek & jatidiri \\
koperasi & padda \\
tahun 2014 & "Cukup \\
Sehat" & yaitu \\
memperoleh & skor \\
69,15 dan & pada \\
tahun 2015 & juga \\
"Cukup Sehat" yaitu \\
memperoleh r & skor \\
$70,73$. & \\
\end{tabular} \\
\hline 2 & $\begin{array}{l}\text { Wijayanti } \\
2012\end{array}$ & $\begin{array}{l}\text { Evaluasi } \\
\text { Kinerja } \\
\text { Keuangann } \\
\text { Koperasi } \\
\text { Simpan } \\
\text { Pinjam di } \\
\text { Kabupaten } \\
\text { Kulonprogo } \\
\text { Tahun 2009- } \\
2010 .\end{array}$ & $\begin{array}{l}\text { Persamaannya } \\
\text { adalah variabel } \\
\text { yang digunakan } \\
\text { aspek permodalan, } \\
\text { kualitas aktiva } \\
\text { produktif, efisiensi, } \\
\text { serta likuiditas. }\end{array}$ & $\begin{array}{l}\text { Objek yang di } \\
\text { evaluasi yaitu } \\
\text { membandingkan } \\
\text { koperasi } \\
\text { berbasis } \\
\text { syari"ah dan } \\
\text { koperasi } \\
\text { Konvensional. }\end{array}$ & $\begin{array}{lr}\text { Hasil } & \text { penelitian } \\
\text { menunjukkan } & \text { nahwa } \\
\text { kinerja } & \text { aspek } \\
\text { keuangan } & \text { dan } \\
\text { manajemen } & \text { KSP di } \\
\text { Kabupaten } & \\
\text { Kulonprogo } & \text { tahun } \\
2009-2010 & \text { dalam } \\
\text { kategori } & \text { "Cukup } \\
\text { Sehat" } & \text { dengan } \\
\text { perolehan skor rata- } & \\
\text { rata } 73,6 . & \end{array}$ \\
\hline 3 & $\begin{array}{l}\text { Eidrias } \\
\text { dan } \\
\text { Azizah } \\
2016\end{array}$ & $\begin{array}{l}\text { Analisis } \\
\text { Tingkat } \\
\text { Kesehatan } \\
\text { Koperasi } \\
\text { Simpan } \\
\text { Pinjam } \\
\text { Berdasarkan } \\
\text { Peraturan } \\
\text { Nomor: } \\
\text { 06/Per/Dep.6/l } \\
\text { V/2016 (Studi } \\
\text { Kasus pada } \\
\text { Koperasi } \\
\text { Simpan } \\
\text { Pinjam } \\
\text { Bahagia kota } \\
\text { Kediri). }\end{array}$ & 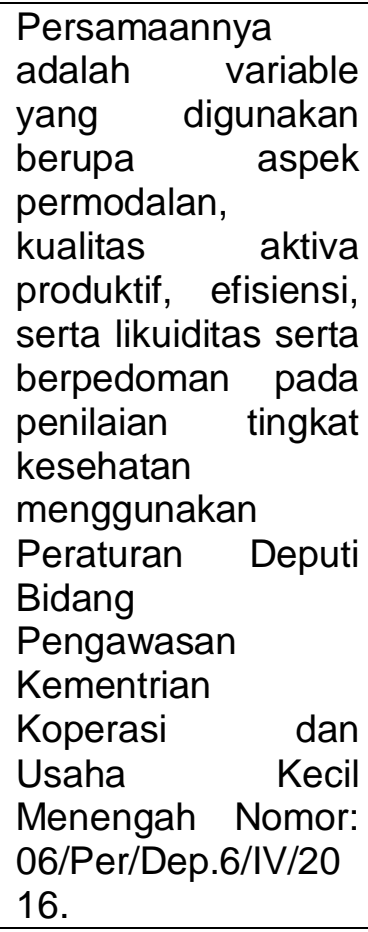 & $\begin{array}{l}\text { Subjek } \\
\text { mencakup } \\
\text { Koperasi dalam } \\
\text { satu kecamatan } \\
\text { Bantul. }\end{array}$ & $\begin{array}{lr}\text { Hasil penelitian } \\
\text { menunjukkan } \\
\text { penilaian kesehatan } \\
\text { koperasi simpan } \\
\text { pinjam bahagia } \\
\text { berdasarkan } \\
\text { peraturan nomor: } \\
06 / \text { Per/Dep.6/IV/201 } \\
6 \text { dilihat dari hasil } \\
\text { skor keseluruhan } \\
\text { dikategorikan dalam } \\
\text { keadaan "Cukup } \\
\text { Sehat" dengan hasil } \\
\text { skor } 70,75 .\end{array}$ \\
\hline
\end{tabular}




\section{METODE PENELITIAN}

Menurut Sugiyono (2016:60) Variabel Penelitian adalah suatu atribut atau sifat atau nilai dari orang, objek atau kegiatan yang mempunyai variansi tertentu yang ditetapkan oleh peneliti untuk dipelajari sehingga diperoleh informasi tentang hal tersebut, kemudian ditarik kesimpulannya.

\section{1) Objek dan Waktu Penelitian}

Penelitian ini dilakukan di Koperasi Unit Desa Maju Bersama Kecamatan Rambang Kabupaten Muara Enim.Waktu observasi dilakukan pada tanggal 25 Maret 2019 sampai 28 Maret 2019, dan waktu penelitian dilakukan pada bulan Mei 2019.

\section{2) Definsi Operasional Variabel}

Variabel dalam penelitian ini adalah Kinerja Keuangan Koperasi Unit Desa Maju Bersama (KUD Maju Bersama) Desa Kencana Mulia kecamatan Rambang.Adapun dimaksud dengan kinerja keuangan KUD Maju Bersama yaitu prestasi yang dicapai oleh KUD maju bersama dilihat dari aspek permodalan, aspek kualitas aktiva produktif, aspek efisiensi, serta aspek likuiditas koperasi.

Tabel Definisi Operasional Variabel

\begin{tabular}{|c|c|c|c|}
\hline Variabel & Pengertian & Indikator & Rumus \\
\hline $\begin{array}{l}\text { Kineja } \\
\text { Keuangan } \\
\text { koperasi }\end{array}$ & \begin{tabular}{|l|} 
Kinerja \\
keuangan \\
merupakan \\
suatu analisis \\
yang dilakukan \\
untuk melihat \\
sejauh mana \\
suatu \\
perusahaan \\
telah \\
melaksanakan \\
dengan \\
menggunakan \\
aturan-atuaran \\
pelaksanaan \\
keangan \\
secara baik dan \\
benar. Fahmi \\
(2012)
\end{tabular} & $\begin{array}{l}\text { 2. Kualitas } \\
\text { aktiva } \\
\text { produktif; }\end{array}$ & 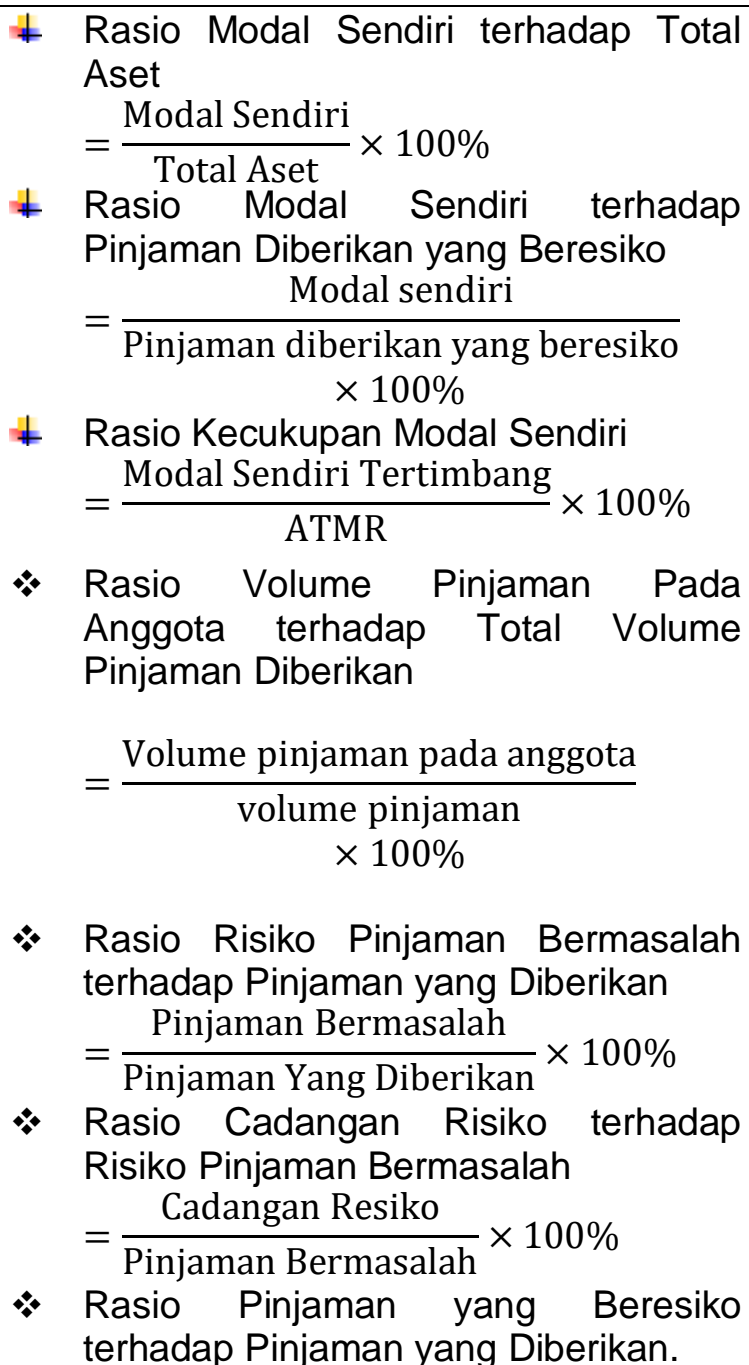 \\
\hline
\end{tabular}




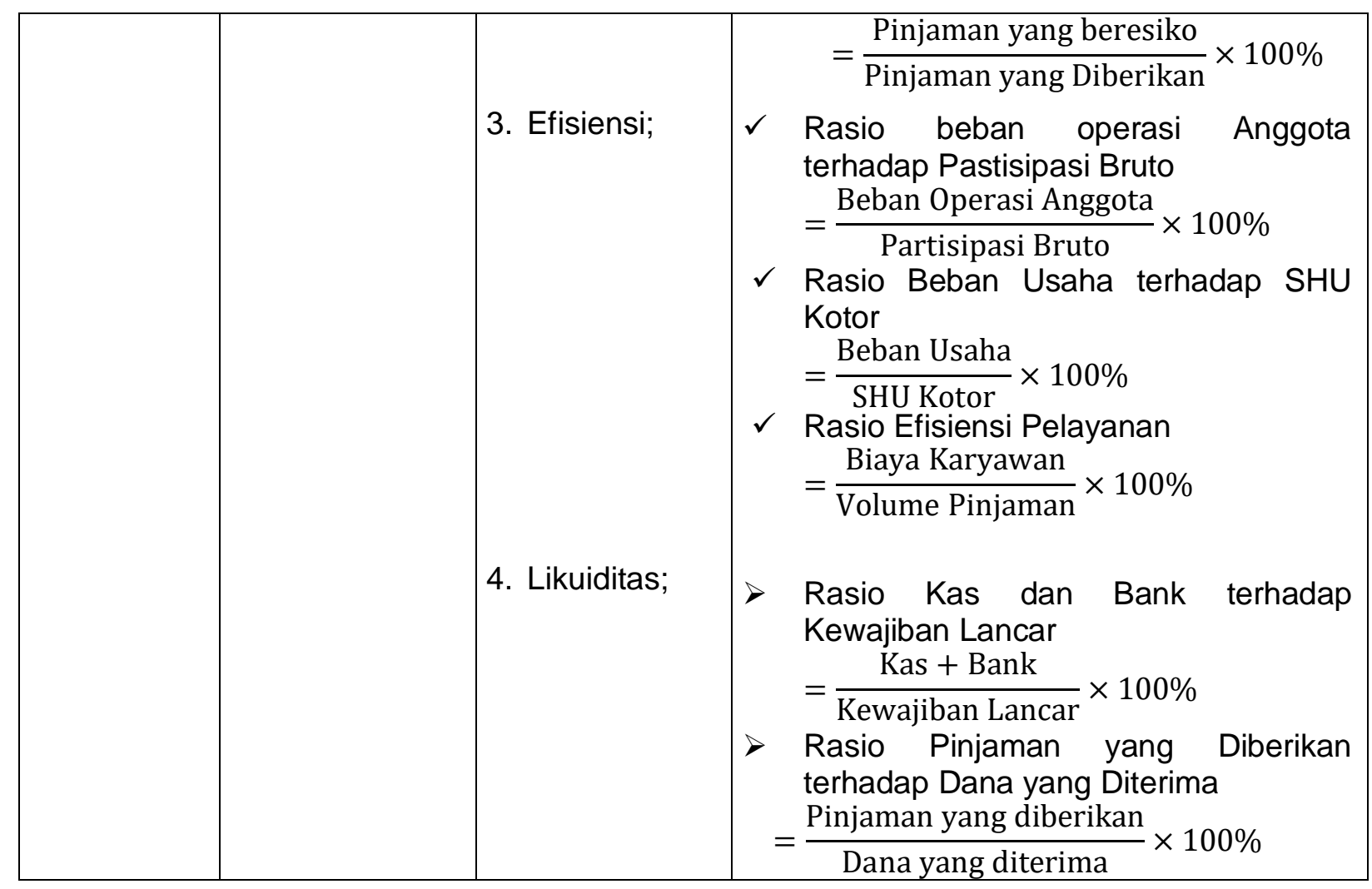

\section{3) Populasi dan Sampel}

a) Populasi

Menurut (Sugiyono 2016:117) Populasi adalah wilayah generalisasi yang terdiri atas : obyek atau subyek yang mempunyai kualitas dan karakteristik tertentu yang ditetapkan oleh peneliti untuk dipelajari dan kemudian ditarik kesimpulannya.

Adapun Populasi dalam penelitian ini adalah Laporan Keuangan Koperasi dari hasil Rapat Anggota Tahunan (RAT) Koperasi Unit Desa Maju Bersama Desa Kencana Mulia Kecamatan Rambang Tahun 2016 - 2018.

b) Sampel

Sampel adalah bagian dari jumlah dan karateristik yang dimiliki oleh populasi tersebut.Bila populasi lebih besar dan peneliti tidak mungkin mempelajari semua yang ada pada populasi, misalnya karena keterbatasan waktu, dana, dan tenaga, maka peneliti dapat menggunakan sampel yang diambil dari populasi itu (Sugiyono 2016:118). Sampel yang digunakan dalam penelitian berupa purposive sampling yaitu salah satu teknik sampel non random dimana peneliti menentukan pengambilan sampel dengan cara menetapkan ciri-ciri khusus yang sesuai dengan tujuan peneliatian hingga diharapkan dapat menjawab permasalahan penelitian. Adapaun dalam penelitian ini sampel yang digunakan terbatas pada laporan keuangan berupa neraca dan laporan laba/rugi.

\section{4) Sumber dan Jenis Data}

Data adalah informasi yang diperoleh peneliti untuk diolah dalam pembahasan dan akan menghasilkan sebuah kesimpulan dalam penelitian ini. Menurut Sugiyono (2016:118) ditinjau dari sisi sumber data penelitian dibagi menjadi: 
1. Data Primer merupakan sumber data yang diperoleh peneliti secara langsung.

2. Data Sekunder adalah sumber data yang diperoleh peneliti dari sumber yang sudah ada, misalnya buku, catatan,bukti yang sudah ada, atau arsip.

Dalam penelitian ini peneliti menggunakan data sekunder berupa buku laporan RAT (Rapat Anggota Tahunan) yang didalamnya sudah terdapat laporan keuangan dari tahun 2016-2018.

\section{5) Teknik Pengumpulan Data}

Dalam rangka pengumpulan data-data untuk menunjang terlaksananya penyusunan penelitian ini, maka pengumpulan data dilakukan dengan menggunakan dua metode yaitu sebagai berikut:

a) Wawancara

Wawancara merupakan metode pengumpulan data dengan bertanya langsung kepada karyawan, dimana peneliti menyampaikan pertanyaan-pertanyaan kepada karyawan untuk menjawabnya.

b) Dokumentasi.

Metode ini merupakan metode pengumpulan data mengenai hal-hal atau variable yang berupa catatan-catatan, transkip-transkip, notulen rapat, dan sebagainya.Dari hasil dokumentasi ini peneliti mendapat data brupa laporan RAT (Rapat Anggota Tahunan) Koperasi Unit Desa maju Bersama Desa kencana Mulia Kecamatan Rambang Kabupaten Muara Enim tahun 2016-2018 yang didalamnya terdapat laporan keuangan dan laporan hasil pemeriksaan yang nantinya digunakan untuk penulisan analis.

\section{6) Teknik Analisis Data}

Dalam penelitian ini peneliti menggunakan teknik analisis data deskriptif kualitatif dengan menggunakan 4 (empat) aspek yang ada dalam Peraturan Deputi Bidang Pengawasan Kementrian Koperasi dan Usaha Kecil dan Menengah No.06/Per/Dep.6/IV/2016 tentang Pedoman Penilaian Koperasi Simpan Pinjam dan Unit Simpan Pinjam Koperasi.

\section{HASIL PENELITIAN \\ 1. Analisis Data}

Analisis data yang digunakan dalam penelitian ini menggunakan analisis deskriptif kualitatif dengan menggunakan 4 (empat) aspek yang ada dalam Peraturan Deputi Bidang Pengawasan Kementrian Koperasi dan Usaha Kecil dan Menengah No.06/Per/Dep.6/IV/2016 tentang Pedoman Penilaian Koperasi Simpan Pinjam dan Unit Simpan Pinjam Koperasi.Dimana penilaian tersebut adalah aspek permodalan, kualitas aktiva produktif, efisiensi, serta likuiditas. Hasil dari analisis tersebut akan memberikan gambaran mengenai tingkat kesehatan Unit Simpan Pinjam Koperasi pada KUD Maju Bersama Desa Kencana Mulia. Adapun langkah-langkah yang dilakukan adalah sebagai berikut:

a. Analsis Penilaian Aspek Kesehatan Koperasi Unit Desa (KUD) Maju Bersama Desa Kencana Mulia Kecamatan Rambang.

Dalam melakukan penilaian dari masing-masing aspek terhadap penilaian kesehatan koperasi yaitu terlebih dahulu diawali dengan menghitung rasio-rasio dari masing-masing aspek. Hasil dari perhitungan rasio akan 
digunakan untuk mencari skor masing-masing aspek. Berikut penjelasan dari masing-masing aspek:

1) Permodalan

Penilaian aspek permodalan ini dimaksudkan untuk mengetahui informasi mengenai kecukupan modal Koperasi Unit Desa Maju Bersama dalam mendukung kegiatan operasionalnya. Selain itu, penilaian aspek ini juga dapat digunakan untuk mengetahui kemampuan Koperasi Unit Desa Maju Bersama dalam menyerap kerugian akibat investasi dan penuruan nilai aktiva. Penilaian terhadap aspek permodalan Koperasi Unit Desa Maju Bersama didasarkan pada 3 (tiga) rasio, yaitu: rasio modal sendiri terhadap total aset, rasio modal sendiri terhadap pinjaman diberikan yang berisiko, rasio kecukupan modal sendiri. Hasil penilaian terhadap aspek permodalan Koperasi Unit Desa Maju Bersama adalah sebagai berikut:

a) Rasio Modal Sendiri Terhadap Total Aset

Rasio modal sendiri terhadap total asetini dimaksudkan untuk mengukur kemampuan modal sendiri Koperasi Unit Desa Maju Bersama dalam mendukung pendanaan terhadap total aset yang dimilikinya. Berikut ini merupakan hasil perhitungan rasio modal sendiri terhadap total aset di Koperasi Unit Desa Maju Bersama pada tahun 2016-2018:

Rasio Modal Sendiri Terhadap Total Aset $=\frac{\text { modal sendiri }}{\text { total aset }} \times 100 \%$

Tahun $2016=\frac{763.253 .658}{986.309 .417} \times 100 \%=77,38 \%$

Tahun $2017=\frac{814.442 .507}{1.096 .268 .532} \times 100 \%=74,29 \%$

Tahun $2018=\frac{827.277 .507}{1 \cdot 082.703 .009} \times 100 \%=76,40 \%$

Tabel Perhitungan Rasio Modal Sendiri terhadap Total Aset Tahun 2016-2018

\begin{tabular}{|c|c|c|c|}
\hline Tahun & Modal sendiri & Total aset & Rasio (\%) \\
\hline 2016 & 763.253 .658 & 986.309 .417 & 77,38 \\
\hline 2017 & 814.442 .507 & 1.096 .268 .532 & 74,29 \\
\hline 2018 & 827.277 .933 & 1.082 .703 .009 & 76,40 \\
\hline
\end{tabular}

Sumber: Lap. Keuangan KUD Maju Bersama tahun 2016-2018 (data diolah)

Setelah besarnya rasio diketahui, langkah selanjutnya yaitu melakukan penskoran sesuai dengan Peraturan Deputi Bidang Pengawasan Kementerian Koperasi dan UKM Nomor 6 tahun 2016. Untuk penskoran rasio modal sendiri terhadap total aset di Koperasi Unit Desa Maju Bersama tahun 2016-2018 dapat dilihat dalam tabel berikut:

Skor $=$ nilai $\times$ bobot

- Tahun 2016 nilai $50=50 \times 6 \%=3,00$

- Tahun 2017 nilai $50=50 \times 6 \%=3,00$

- Tahun 2018 nilai $50=50 \times 6 \%=3,00$ 
Tabel Penskoran Rasio Modal Sendiri Terhadap Total Aset Koperasi Unit Desa Maju Bersama tahun 2016-2018

\begin{tabular}{|c|c|c|c|c|}
\hline Tahun & Rasio (\%) & Nilai & Bobot (\%) & Skor \\
\hline 2016 & 77,38 & 50 & 6 & 3,00 \\
\hline 2017 & 74,29 & 50 & 6 & 3,00 \\
\hline 2018 & 76,40 & 50 & 6 & 3,00 \\
\hline \multicolumn{5}{|c|}{ Sumber: Perhitungan Rasio-Rasio Aspek Penilaian Kesehatan } \\
KUD Maju Bersama tahun 2016-2018
\end{tabular}

b) Rasio modal sendiri terhadap pinjaman yang diberikan yang berisiko

Rasio modal sendiri terhadap pinjaman diberikan yang berisiko ini dimaksudkan untuk mengukur kemampuan modal sendiri Koperasi Unit Desa Maju Bersama dalam menutup risiko atas pemberian pinjaman yang tidak didukung dengan agunan yang memadai. Berikut ini merupakan hasil pehitungan rasio modal sendiri terhadap pinjaman diberikan yang berisiko di Koperasi Unit Desa Maju Bersama pada tahun 2016-2018:

Rasio modal sendiri terhadap pinjaman yang diberikan yang berisiko

$$
\begin{aligned}
& =\frac{\text { modal sendiri }}{\text { pinjaman berisiko }} \times 100 \% \\
\text { Tahun } 2016= & \frac{763.253 .658}{137.762 .925} \times 100 \%=554,03 \% \\
\text { Tahun } 2017= & \frac{814.442 .507}{162.753 .166} \times 100 \%=500,41 \% \\
\text { Tahun } 2018= & \frac{827.277 .507}{149.922 .156} \times 100 \%=121,58 \%
\end{aligned}
$$

Tabel Perhitungan Rasio Modal Sendiri Terhadap Pinjaman Yang Diberikan yang berisiko tahun 2016-2018

\begin{tabular}{|c|c|c|c|}
\hline Tahun & $\begin{array}{c}\text { Modal } \\
\text { sendiri }\end{array}$ & $\begin{array}{c}\text { Pinjaman diberikan } \\
\text { berisiko }\end{array}$ & Rasio(\%) \\
\hline 2016 & 763.253 .658 & 137.762 .925 & 554,03 \\
\hline 2017 & 814.442 .507 & 162.753 .166 & 500,41 \\
\hline 2018 & 827.277 .507 & 149.922 .156 & 121,58 \\
\hline
\end{tabular}

Sumber: Lap. Keuangan KUD Maju Bersama tahun 2016-2018 (data telah diolah)

Setelah besarnya rasio diketahui, langkah selanjutnya yaitu melakukan penskoran sesuai dengan Peraturan Deputi Bidang Pengawasan Kementerian Koperasi dan UKM Nomor 6 tahun 2016. Untuk penskoran rasio modal sendiri terhadap pinjaman diberikan yang berisiko di Koperasi Unit Desa Maju Bersama tahun 2016-2018 dapat dilihat dalam tabel berikut:

Skor $=$ nilai $\times$ bobot

- Tahun 2016 nilai $100=100 \times 6 \%=6,00$

- Tahun 2017 nilai $100=100 \times 6 \%=6,00$

- Tahun 2018 nilai $100=100 \times 6 \%=6,00$

Tabel Perskoran Rasio Modal Sendiri Terhadap Pinjaman Diberikan Yang Berisiko di KUD Maju Bersama Tahun 2016-2018

\begin{tabular}{|c|c|c|c|c|}
\hline Tahun & Rasio(\%) & nilai & Bobot(\%) & Skor \\
\hline 2016 & 554,03 & 100 & 6 & 6,00 \\
\hline
\end{tabular}




\begin{tabular}{|l|l|l|l|l|}
\hline 2017 & 500,41 & 100 & 6 & 6,00 \\
\hline 2018 & 121,58 & 100 & 6 & 6,00 \\
\hline
\end{tabular}

Sumber: Perhitungan Rasio-Rasio Aspek Penilaian Kesehatan

Koperasi Unit Desa Maju Bersama tahun 2016-2018

c) Rasio kecukupan modal sendiri

Rasio kecukupan modal sendiri ini dimaksudkan untuk mengukur kemampuan modal sendiri tertimbang Koperasi Unit Desa Maju Bersama dalam menyerap kerugian akibat penurunan aktiva tertimbang yang dimilikinya. Berikut ini merupakan hasil perhitungan rasio kecukupan modal sendiri di Koperasi Unit Desa Maju Bersama pada tahun 2016-2018:

Rasio kecukupan modal sendiri $=\frac{\text { Modal Tertimbang }}{A T M R} \times 100 \%$

Tahun $2016=\frac{820.444 .902}{325.493 .596} \times 100 \%=252,10 \%$

Tahun $2017=\frac{909.859 .113}{354.651 .793} \times 100 \%=256,55 \%$

Tahun $2018=\frac{600.591 .113}{331.469 .639} \times 100 \%=181,19 \%$

Tabel Perhitungan Rasio Kecukupan Modal Sendiri Di Koperasi Unit Desa Maju Bersama tahun 2016-2018

\begin{tabular}{|c|c|c|c|}
\hline Tahun & Modal tertimbang & ATMR & Rasio(\%) \\
\hline 2016 & 820.444 .902 & 325.439 .596 & 252,10 \\
\hline 2017 & 909.859 .611 & 354.651 .793 & 256,55 \\
\hline 2018 & 600.591 .113 & 331.469 .639 & 181,19 \\
\hline
\end{tabular}

Sumber: Lap. Keuangan KUD Maju Bersama tahun 2016-2018 (data diolah)

Setelah besarnya rasio diketahui, langkah selanjutnya yaitu melakukan penskoran sesuai dengan Peraturan Deputi Bidang Pengawasan Kementerian Koperasi dan UKM Nomor 6 tahun 2016. Untuk penskoran rasio kecukupan modal sendiri di KUD Maju Bersama pada tahun 2016-2018 dapat dilihat dalam tabel berikut:

Skor = nilai $\times$ bobot

- Tahun 2016 nilai $100=100 \times 3 \%=3,00$

- Tahun 2017 nilai $100=100 \times 3 \%=3,00$

- Tahun 2018 nilai $50=100 \times 3 \%=3,00$

Tabel Penskoran Rasio Kecukupan Modal Sendiri di Koperasi Unit Desa Maju Bersama tahun 2016-2018

\begin{tabular}{|c|c|c|c|c|}
\hline Tahun & Rasio(\%) & Nilai & Bobot(\%) & Skor \\
\hline 2016 & 252,10 & 100 & 3 & 3,00 \\
\hline 2017 & 256,55 & 100 & 3 & 3,00 \\
\hline 2018 & 181,19 & 100 & 3 & 3,00 \\
\hline
\end{tabular}

Sumber: Perhitungan Rasio-Rasio Aspek Penilaian Kesehatan Koperasi Unit Desa Maju Bersama tahun 2016-2018 
2) Kualitas Aktiva Produktif

Penilaian aspek kualitas aktiva produktif ini dimaksudkan untuk mengukur kekayaan KSP/USP Koperasi dalam mendatangkan penghasilan bagi koperasi tersebut. Penilaian terhadap aspek kualitas aktiva produktif Koperasi Unit Desa Maju Bersama didasarkan pada 4 (empat) rasio yaitu rasio volume pinjaman pada anggota terhadap volume pinjaman yang diberikan, rasio risiko pinjaman bermasalah terhadap pinjaman yang diberikan, rasio cadangan risiko terhadap pinjaman yang diberikan, dan rasio pinjaman yang berisiko terhadap pinjaman yang diberikan. Hasil penilaian terhadap aspek kualitas aktiva produktif Koperasi Unit Desa Maju Bersama adalah sebagai berikut:

a) Rasio volume pinjaman pada anggota terhadap volume injaman diberikan

Rasio volume pinjaman pada anggota terhadap volume pinjaman yang diberikan ini dimaksudkan untuk mengukur kemampuan Koperasi Unit Desa Maju Bersama dalam memenuhi seluruh pinjaman anggotanya. Berikut ini merupakan hasil perhitungan rasio volume pinjaman pada anggota terhadap volume pinjaman yang diberikan di Koperasi Unit Desa Maju Bersama pada tahun 2016-2018:

Rasio volume pinjaman pada anggota terhadap volume injaman diberikan

$$
=\frac{\text { volume pinjaman pada ang gota }}{\text { volume pinjaman }} \times 100 \%
$$

$$
\begin{gathered}
\text { Tahun } 2016=\frac{122.024 .925}{137.762 .925} \times 100 \%=88,57 \% \\
\text { Tahun } 2017=\frac{138.290 .166}{162.753 .166} \times 100 \%=84,06 \% \\
\text { Tahun } 2018=\frac{139.534 .156}{149.922 .156} \times 100 \%=93,07 \%
\end{gathered}
$$

Tabel Perhitungan Rasio Volume Pinjaman Pada Anggota Terhadap Volume Pinjaman Diberikan tahun 2016-2018

\begin{tabular}{|c|c|c|c|}
\hline Tahun & $\begin{array}{c}\text { Volume Pinjaman } \\
\text { Pada Anggota }\end{array}$ & $\begin{array}{c}\text { Volume } \\
\text { Pinjaman }\end{array}$ & Rasio(\%) \\
\hline 2016 & 122.024 .925 & 137.762 .925 & 88,57 \\
\hline 2017 & 138.290 .166 & 162.753 .166 & 84,06 \\
\hline 2018 & 139.534 .156 & 149.922 .156 & 93,07 \\
\hline
\end{tabular}

Sumber: Lap. Keuangan KUD Maju Bersama tahun 2016-2018 (data diolah)

Setelah besarnya rasio diketahui, langkah selanjutnya yaitu melakukan penskoran sesuai dengan Peraturan Deputi Bidang Pengawasan Kementerian Koperasi dan UKM Nomor 6 tahun 2016. Untuk penskoran rasio volume pinjaman pada anggota terhadap volume pinjaman yang diberikan di Koperasi Unit Desa Maju Bersama tahun 2016-2018 dapat dilihat dalam tabel berikut:

$$
\begin{aligned}
\text { Skor }=\text { nilai } \times \text { bobot } \\
\text { - Tahun } 2016 \text { nilai } 10=10 \times 10 \%=1,00 \\
\text { - Tahun } 2017 \text { nilai } 10=10 \times 10 \%=1,00 \\
\text { - Tahun } 2018 \text { nilai } 10=10 \times 10 \%=1,00
\end{aligned}
$$




\section{Tabel Penskoran Rasio Volume Pinjaman Anggota Terhadap Volume Pinjaman Yang Diberikan di KUD Maju Bersama tahun 2016-2018}

\begin{tabular}{|c|c|c|c|c|}
\hline Tahun & Rasio (\%) & Nilai & Bobot(\%) & Skor \\
\hline 2016 & 88,57 & 10 & 10 & 1,00 \\
\hline 2017 & 84,06 & 10 & 10 & 1,00 \\
\hline 2018 & 93,07 & 10 & 10 & 1,00 \\
\hline
\end{tabular}

Sumber: Perhitungan Rasio-Rasio Aspek Penilaian Kesehatan Koperasi Unit Desa Maju Bersama tahun 2016-2018

b) Rasio pinjaman bermasalah terhadap pinjaman yang diberikan

Rasio risiko pinjaman bermasalah terhadap pinjaman yang diberikan dimaksudkan untuk mengukur besarnya risiko pinjaman bermasalah dari seluruh pinjaman yang diberikan. Berikut ini merupakan hasil perhitungan rasio risiko pinjaman bermasalah terhadap pinjaman yang diberikan di Koperasi Unit Desa Maju Bersama pada tahun 2016-2018:

Rasio pinjaman bermasalah terhadap pinjaman yang diberikan

$$
=\frac{\text { pinjaman bermasalah }}{\text { pinjaman diberikan }} \times 100 \%
$$

Tahun $2016=\frac{20.400 .000}{137.762 .925} \times 100 \%=14,80 \%$

Tahun $2017=\frac{25.800 .000}{162.753 .166} \times 100 \%=15,85 \%$

Tahun $2018=\frac{31.200 .000}{149.922 .156} \times 100 \%=20,81 \%$

Tabel Perhitungan Rasio Risiko Pinjaman Bermasalah Terhadap Pinjaman Yang Diberikan di KUD Maju Bersama Tahun 2016-2018

\begin{tabular}{|l|c|c|c|}
\hline Tahun & $\begin{array}{c}\text { Pinjaman } \\
\text { Bermasalah }\end{array}$ & $\begin{array}{c}\text { Pinjaman } \\
\text { Diberikan }\end{array}$ & Rasio(\%) \\
\hline 2016 & 20.400 .000 & 137.762 .925 & 14,80 \\
\hline 2017 & 25.800 .000 & 162.753 .166 & 15.85 \\
\hline 2018 & 31.200 .000 & 149.922 .156 & 20,81 \\
\hline \multicolumn{4}{|c|}{ Sumber: Lap. Keuangan Koperasi Unit Desa Maju Bersama } \\
Tahun 2016-2018 (data diolah)
\end{tabular}

Setelah besarnya rasio diketahui, langkah selanjutnya yaitu melakukan penskoran sesuai dengan Peraturan Deputi Bidang Pengawasan Kementerian Koperasi dan UKM Nomor 6 tahun 2016. Untuk penskoran rasio risiko pinjaman bermasalah terhadap pinjaman yang diberikan di Koperasi Unit Desa Maju Bersama pada tahun 20162018 dapat dilihat dalam tabel berikut:

Skor $=$ nilai $\times$ bobot

- Tahun 2016 nilai $80=80 \times 5 \%=4,00$

- Tahun 2017 nilai $60=60 \times 5 \%=3,00$

- Tahun 2018 nilai $60=60 \times 5 \%=3,00$ 
Tabel Penskoran Rasio Risiko Pinjaman Bermasalah Terhadap Pinjaman Yang Diberikan di KUD Maju Bersama Tahun 2016-2018

\begin{tabular}{|c|c|c|c|c|}
\hline Tahun & Rasio (\%) & Nilai & Bobot(\%) & Skor \\
\hline 2016 & 14,80 & 80 & 5 & 4,00 \\
\hline 2017 & 15,85 & 60 & 5 & 3,00 \\
\hline 2018 & 20,81 & 60 & 5 & 3,00 \\
\hline \multicolumn{5}{|c|}{ Sumber: Perhitungan Rasio-Rasio Aspek Penilaian Kesehatan } \\
Koperasi Unit Desa Maju Bersama tahun 2016-2018
\end{tabular}

c) Rasio cadangan resiko terhadap pinjaman yang diberikan

Rasio cadangan risiko terhadap risiko pinjaman bermasalah dimaksudkan untuk mengukur kualitas cadangan risiko dalam mengatasi risiko pinjaman yang bermasalah. Berikut ini merupakan hasil perhitungan rasio cadangan risiko terhadap risiko pinjaman bermasalah di KUD Maju Bersama pada tahun 2016-2018:

Rasio cadangan resiko terhadap pinjaman yang diberikan

$$
\begin{aligned}
& =\frac{\text { cadangan risiko }}{\text { pinjaman bermasalah }} \times 100 \% \\
& \text { Tahun } 2016=\frac{0}{20.400 .000} \times 100 \%=0 \% \\
& \text { Tahun } 2017=\frac{0}{25.800 .000} \times 100 \%=0 \% \\
& \text { Tahun } 2018=\frac{0}{31.200 .000} \times 100 \%=0 \%
\end{aligned}
$$

Tabel Perhitungan Rasio Cadangan Risiko Terhadap Risiko Pinjaman Bermasalah di KUD Maju Bersama tahun 2016-2018

\begin{tabular}{|c|c|c|c|}
\hline Tahun & $\begin{array}{c}\text { Cadangan } \\
\text { Risiko }\end{array}$ & $\begin{array}{c}\text { Pinjaman } \\
\text { Bermaslah }\end{array}$ & Rasio(\%) \\
\hline 2016 & - & 20.400 .000 & 0 \\
\hline 2017 & - & 25.800 .000 & 0 \\
\hline 2018 & - & 31.200 .000 & 0 \\
\hline \multicolumn{2}{|r|}{ Sumber: Lap. Keuangan KUD Maju Bersama tahun 2016-2018 (data diolah) }
\end{tabular}

Setelah besarnya rasio diketahui, langkah selanjutnya yaitu melakukan penskoran sesuai dengan Peraturan Deputi Bidang Pengawasan Kementerian Koperasi dan UKM Nomor 6 tahun 2016. Untuk penskoran rasio cadangan risiko terhadap risiko pinjaman bermasalah di Koperasi Unit Desa Maju Bersama pada tahun 2016 2018 dapat dilihat dalam tabel berikut:

Skor = nilai $\times$ bobot

- Tahun 2016 nilai $0=0 \times 5 \%=0$

- Tahun 2017 nilai $0=0 \times 5 \%=0$

- Tahun 2018 nilai $0=0 \times 5 \%=0$

Tabel Penskoran Rasio Cadangan Risiko Terhadap Risiko Pinjaman Bermasalah di KUD Maju Bersama tahun 2016-2018

\begin{tabular}{|c|c|c|c|c|}
\hline Tahun & Rasio (\%) & Nilai & Bobot(\%) & Skor \\
\hline 2016 & 0 & 0 & 5 & 0 \\
\hline
\end{tabular}




\begin{tabular}{|l|l|l|l|l|}
\hline 2017 & 0 & 0 & 5 & 0 \\
\hline 2018 & 0 & 0 & 5 & 0 \\
\hline
\end{tabular}

Sumber: Perhitungan Rasio-Rasio Aspek Penilaian Kesehatan Koperasi Unit Desa Maju Bersama tahun 2016-2018

d) Rasio pinjaman berisiko terhadap pinjaman yang diberikan

Rasio pinjaman yang berisiko terhadap pinjaman yang diberikan dimaksudkan untuk mengukur besarnya pinjaman yang berisiko dari seluruh pinjaman yang diberikan. Berikut ini merupakan hasil perhitungan rasio pinjaman yang berisiko terhadap pinjaman yang diberikan di Koperasi Unit Desa Maju Bersama pada tahun 2016-2018:

Rasio pinjaman berisiko terhadap pinjaman yang diberikan

$$
\begin{gathered}
=\frac{\text { pinjaman berisiko }}{\text { pinjaman diberikan }} \times 100 \% \\
\text { Tahun } 2016=\frac{137.762 .925}{137.762 .925} \times 100 \%=100 \% \\
\text { Tahun } 2017=\frac{162.753 .166}{162.753 .166} \times 100 \%=100 \% \\
\text { Tahun } 2018=\frac{149.922 .156}{149.922 .156} \times 100 \%=100 \%
\end{gathered}
$$

Tabel Perhitungan Rasio Pinjaman Yang Berisiko Terhadap Pinjaman Yang Diberikan Di KUD Maju Bersama tahun 2016-2018

\begin{tabular}{|c|c|c|c|}
\hline Tahun & $\begin{array}{c}\text { Pinjaman } \\
\text { Berisiko }\end{array}$ & $\begin{array}{c}\text { Pinjaman } \\
\text { diberikan }\end{array}$ & Rasio(\%) \\
\hline 2016 & 137.762 .925 & 137.762 .925 & 100 \\
\hline 2017 & 162.753 .166 & 162.753 .166 & 100 \\
\hline 2018 & 149.922 .156 & 149.922 .156 & 100 \\
\hline \multicolumn{4}{|r}{ Sumber: Lap. Keuangan KUD Maju Bersama tahun 2016-2018 (data diolah) }
\end{tabular}

Setelah besarnya rasio diketahui, langkah selanjutnya yaitu melakukan penskoran sesuai dengan Peraturan Deputi Bidang Pengawasan Kementerian Koperasi dan UKM Nomor 6 tahun 2016. Untuk penskoran rasio pinjaman yang berisiko terhadap pinjaman yang diberikan di Koperasi Unit Desa Maju Bersama pada tahun 2016-2018 dapat dilihat dalam tabel berikut:

Skor = nilai $\times$ bobot

- $\quad$ Tahun 2016 nilai $25=25 \times 5 \%=1,25$

- Tahun 2017 nilai $25=25 \times 5 \%=1,25$

- Tahun 2018 nilai $25=25 \times 5 \%=1,25$

Tabel Penskoran Rasio Pinjaman Yang Berisiko Terhadap Pinjaman Yang Diberikan Di KUD Maju Bersama Tahun 2016-2018

\begin{tabular}{|c|c|c|c|c|}
\hline Tahun & Rasio (\%) & Nilai & Bobot(\%) & Skor \\
\hline 2016 & 100 & 25 & 5 & 1,25 \\
\hline 2017 & 100 & 25 & 5 & 1,25 \\
\hline 2018 & 100 & 25 & 5 & 1,25 \\
\hline
\end{tabular}

Sumber: Perhitungan Rasio-Rasio Aspek Penilaian Kesehatan Koperasi Unit Desa Maju Bersama tahun 2016-2018 
3) Efisiensi

Penilaian aspek efisiensi ini dimaksudkan untuk mengukur kemampuan Koperasi Unit Desa Maju Bersama dalam mengendalikan biaya operasionalnya, sehingga semakin kecil pengeluaran biaya operasionalnya berarti semakin efisien koperasi tersebut. Penilaian terhadap aspek efisiensi Koperasi Unit Desa Maju Bersama didasarkan pada 3 (tiga) rasio yaitu: rasio biaya operasional pelayanan terhadap partisipasi bruto, rasio beban usaha terhadap SHU kotor, dan rasio efisiensi pelayanan. Hasil penilaian terhadap aspek efisiensi Koperasi Unit Desa Maju Bersama adalah sebagai berikut:

a) Rasio beban operasi anggota terhadap partisipasi bruto

Penilaian rasio beban operasi anggota terhadap partisipasi bruto dimaksudkan untuk mengetahui besarnya beban operasi anggota yang dikeluarkan KSP/USP Koperasi dalam memperoleh partisipasi bruto. Berikut ini merupakan hasil perhitungan rasio beban operasi anggota terhadap partisipasi bruto di Koperasi Unit Desa Maju Bersama pada tahun 2016-2018:

Rasio beban operasi anggota terhadap partisipasi bruto

$$
=\frac{\text { beban operasi anggota }}{\text { partisipasi bruto }} \times 100 \%
$$

Tahun $2016=\frac{36.540 .547}{276.139 .047} \times 100 \%=13,23 \%$

Tahun $2017=\frac{48.151 .652}{294.796 .366} \times 100 \%=16,33 \%$

Tahun $2018=\frac{42.413 .550}{228.792 .855} \times 100 \%=18,53 \%$

Tabel perhitungan rasio beban operasi anggota terhadap partisipasi bruto di KUD Maju Bersama pada tahun 2016-2018

\begin{tabular}{|c|c|c|c|}
\hline Tahun & $\begin{array}{c}\text { Beban Operasi } \\
\text { Anggota }\end{array}$ & $\begin{array}{c}\text { Partisipasi } \\
\text { Bruto }\end{array}$ & Rasio(\%) \\
\hline 2016 & 36.540 .547 & 276.139 .047 & 13.23 \\
\hline 2017 & 48.151 .652 & 294.796 .366 & 16,33 \\
\hline 2018 & 42.413 .550 & 228.792 .855 & 18,53 \\
\hline
\end{tabular}

Sumber: Lap. Keuangan KUD Maju Bersama tahun 2016-2018 (data telah diolah)

Setelah besarnya rasio diketahui, langkah selanjutnya yaitu melakukan penskoran sesuai dengan Peraturan Deputi Bidang Pengawasan Kementerian Koperasi dan UKM Nomor 6 tahun 2016. Untuk penskoran rasio beban operasional pelayanan terhadap partisipasi bruto di Koperasi Unit Desa Maju Bersama pada tahun 2016-2018 dapat dilihat dalam tabel berikut:

Skor $=$ nilai $\times$ bobot

- Tahun 2016 nilai $100=100 \times 4 \%=4,00$

- Tahun 2017 nilai $100=100 \times 4 \%=4,00$

- Tahun 2018 nilai $100=100 \times 4 \%=4,00$ 
Tabel Penskoran Rasio Beban Operasional Pelayanan Terhadap Partisipasi Bruto Di KUD Maju Bersama Pada Tahun 2016-2018

\begin{tabular}{|c|c|c|c|c|}
\hline Tahun & Rasio (\%) & Nilai & Bobot(\%) & Skor \\
\hline 2016 & 13,23 & 100 & 4 & 4,00 \\
\hline 2017 & 16,33 & 100 & 4 & 4,00 \\
\hline 2018 & 18,53 & 100 & 4 & 4,00 \\
\hline
\end{tabular}

Sumber: Perhitungan Rasio-Rasio Aspek Penilaian Kesehatan Koperasi Unit Desa Maju Bersama tahun 2016-2018

b) Rasio beban usaha terhadap SHU kotor

Rasio beban usaha terhadap SHU kotor ini dimaksudkan untuk mengukur mengetahui besarnya beban usaha yang dikeluarkan Koperasi Unit Desa Maju Bersama dalam memperoleh SHU kotor. Berikut ini merupakan hasil perhitungan rasio beban usaha terhadap SHU kotor di KUD Maju Bersama pada tahun 2016-2018:

$$
\begin{aligned}
& \text { Rasio beban usaha terhadap SHU kotor }=\frac{b e}{S} \\
& \text { Tahun } 2016=\frac{168.083 .152}{71.515 .348} \times 100 \%=235,, 03 \% \\
& \text { Tahun } 2017=\frac{173.286 .121}{73.258 .593} \times 100 \%=236,67 \% \\
& \text { Tahun } 2018=\frac{151.242 .864}{35.236 .441} \times 100 \%=430,44 \%
\end{aligned}
$$

\section{Tabel Perhitungan Rasio Beban Usaha Terhadap SHU Kotor Di} Koperasi Unit Desa Maju Bersama tahun 2016-2018

\begin{tabular}{|c|c|c|c|}
\hline Tahun & Beban Usaha & SHU Kotor & Rasio(\%) \\
\hline 2016 & 168.083 .152 & 71.515 .348 & 235,03 \\
\hline 2017 & 173.386 .121 & 73.258 .593 & 236,67 \\
\hline 2018 & 152.242 .864 & 35.136 .441 & 430,44 \\
\hline
\end{tabular}

Setelah besarnya rasio diketahui, langkah selanjutnya yaitu melakukan penskoran sesuai dengan Peraturan Deputi Bidang Pengawasan Kementerian Koperasi dan UKM Nomor 6 tahun 2016. Untuk penskoran rasio beban usaha terhadap SHU kotor di Koperasi Unit Desa Maju Bersama pada tahun 2016-2018 dapat dilihat dalam tabel berikut:

Skor $=\square \square \square \square \square \times$

Tahun 2016 nilai $25=25 \times 4 \%=1,00$

Tahun 2017 nilai $25=25 \times 4 \%=1,00$

Tahun 2018 nilai $25=25 \times 4 \%=1,00$

Tabel Penskoran Rasio Beban Usaha Terhadap SHU Kotor Di Koperasi Unit Desa Maju Bersama tahun 2016-2018

\begin{tabular}{|c|c|c|c|c|}
\hline Tahun & Rasio (\%) & Nilai & Bobot(\%) & Skor \\
\hline 2016 & 235,03 & 25 & 4 & 1,00 \\
\hline 2017 & 236,67 & 25 & 4 & 1,00 \\
\hline 2018 & 430,44 & 25 & 4 & 1,00 \\
\hline
\end{tabular}


c) Rasio efisiensi pelayanan

Rasio efisiensi pelayanan ini dimaksudkan untuk mengukur besarnya biaya karyawan yang dikeluarkan USP KPRI Bangkit Bersama dalam menjalankan kegiatan simpan pinjam. Hasil perhitungan rasio efisiensi pelayanan di Koperasi Unit Desa Maju Bersama pada tahun 2016-2018 dapat dilihat pada tabel berikut:

$$
\begin{aligned}
& \text { Rasio efisiensi pelayanan }=\frac{\square \square \square \square \square \square \square \square \square \square \square \square \square}{\square \square \square \square \square \square \square \square \square \square \square \square \square \square} \times 100 \% \\
& \text { Tahun } 2016=\frac{80.200 .000}{137.762 .925} \times 100 \%=58,21 \% \\
& \text { Tahun } 2017=\frac{82.500 .000}{162.753 .166} \times 100 \%=50,69 \% \\
& \text { Tahun } 2018=\frac{87.550 .000}{149.922 .156} \times 100 \%=58,39 \%
\end{aligned}
$$

Tabel Perhitungan Rasio Efisiensi Pelayanan Di Koperasi Unit Desa Maju Bersama tahun 2016-2018

\begin{tabular}{|c|c|c|c|}
\hline Tahun & Biaya Karyawan & $\begin{array}{c}\text { Volume } \\
\text { Pinjaman }\end{array}$ & Rasio(\%) \\
\hline 2016 & 80.200 .000 & 137.762 .925 & 58,21 \\
\hline 2017 & 82.500 .000 & 162.753 .166 & 50,69 \\
\hline 2018 & 87.550 .000 & 149.922 .156 & 58,39 \\
\hline
\end{tabular}

Sumber: Lap. Keuangan KUD Maju Bersama tahun 2016-2018 (data diolah)

Setelah besarnya rasio diketahui, langkah selanjutnya yaitu melakukan penskoran sesuai dengan Peraturan Peraturan Deputi Bidang Pengawasan Kementerian Koperasi dan UKM Nomor 6 tahun 2016. Untuk penskoran rasio efisiensi pelayanan di Koperasi Unit Desa Maju Bersama pada tahun 2016-2018 dapat dilihat dalam tabel berikut:

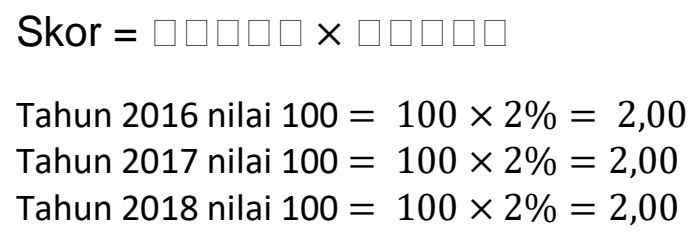

Tabel Penskoran Rasio Efisiensi Pelayanan Di Koperasi Unit Desa Maju Bersama pada tahun 2016-2018

\begin{tabular}{|c|c|c|c|c|}
\hline Tahun & Rasio (\%) & Nilai & Bobot(\%) & Skor \\
\hline 2016 & 58,21 & 100 & 2 & 2,00 \\
\hline 2017 & 50,69 & 100 & 2 & 2,00 \\
\hline 2018 & 58,39 & 100 & 2 & 2,00 \\
\hline
\end{tabular}

Sumber: Perhitungan Rasio-Rasio Aspek Penilaian Kesehatan Koperasi Unit Desa Maju Bersama tahun 2016-2018

4) Likuiditas

Penilaian aspek likuiditas ini dimaksudkan untuk mengukur kemampuan Unit Desa Maju Bersama dalam memenuhi kewajiban jangka pendeknya. Penilaian terhadap aspek likuiditas Unit Desa Maju Bersama didasarkan pada 2 (dua) rasio yaitu rasio kas dan bank terhadap kewajiban lancar dan rasio pinjaman yang diberikan terhadap dana yang 
diterima. Hasil penilaian terhadap aspek likuiditas Unit Desa Maju Bersama adalah sebagai berikut:

a) Rasio kas dan bank terhadap kewajiban lancar

Rasio kas dan bank terhadap kewajiban lancar ini dimaksudkan untuk mengukur kemampunan Unit Desa Maju Bersama dalam membayar hutang jangka pendeknya dengan menggunakan kas dan bank yang dimiliki koperasi. Berikut ini merupakan hasil perhitungan rasio kas dan bank terhadap kewajiban lancar di Unit Desa Maju Bersama pada tahun 2016-2018:

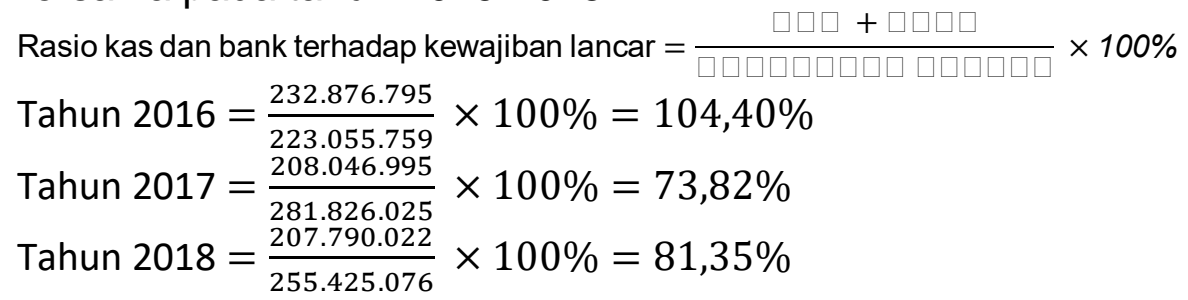

Tabel Perhitungan Rasio Kas Dan Bank Terhadap Kewajiban Lancar Di Koperasi Unit Desa Maju Bersama Tahun 2016-2018

\begin{tabular}{|c|c|c|c|}
\hline Tahun & Kas + Bank & $\begin{array}{c}\text { Kewajiban } \\
\text { Lancar }\end{array}$ & Rasio(\%) \\
\hline 2016 & 232.876 .795 & 223.055 .759 & 104,40 \\
\hline 2017 & 208.046 .995 & 281.826 .025 & 73,82 \\
\hline 2018 & 207.790 .022 & 255.425 .076 & 81,35 \\
\hline
\end{tabular}

Sumber: Lap. Keuangan KUD Maju Bersama tahun 2016-2018 (data diolah)

Setelah besarnya rasio diketahui, langkah selanjutnya yaitu melakukan penskoran sesuai dengan Peraturan Deputi Bidang Pengawasan Kementerian Koperasi dan UKM Nomor 6 tahun 2016. Untuk penskoran rasio kas dan bank terhadap kewajiban lancar di Unit Desa Maju Bersama pada tahun 2016-2018 dapat dilihat dalam tabel berikut:

Skor $=$

Tahun 2016 nilai $25=25 \times 10 \%=2,50$

Tahun 2017 nilai $25=25 \times 10 \%=2,50$

Tahun 2018 nilai $25=25 \times 10 \%=2,50$

Tabel Penskoran Rasio Kas Dan Bank Terhadap Kewajiban Lancar Di KUD Maju Bersama Pada Tahun 2016-2018

\begin{tabular}{|c|c|c|c|c|}
\hline Tahun & Rasio (\%) & Nilai & Bobot(\%) & Skor \\
\hline 2016 & 104,40 & 25 & 10 & 2,5 \\
\hline 2017 & 73,82 & 25 & 10 & 2,5 \\
\hline 2018 & 81,35 & 25 & 10 & 2,5 \\
\hline
\end{tabular}

Sumber: Perhitungan Rasio-Rasio Aspek Penilaian Kesehatan Koperasi Unit Desa Maju Bersama tahun 2016-2018

b) Rasio pinjaman yang diberikan terhadap dana yang diterima

Rasio pinjaman yang diberikan terhadap dana yang diterima ini dimaksudkan untuk mengukur kemampunan Unit Desa Maju Bersama dalam memberikan pinjaman kepada anggota maupun calon anggota 
dengan menggunakan dana yang diterima. Berikut ini merupakan hasil perhitungan rasio pinjaman yang diberikan terhadap dana yang diterima di Unit Desa Maju Bersama pada tahun 2016-2018:

Rasio pinjaman yang diberikan terhadap dana yang diterima

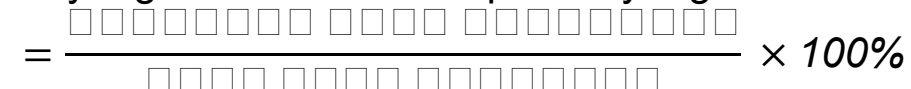

$$
\begin{aligned}
& \text { Tahun } 2016=\frac{137.762 .925}{914.794 .069} \times 100 \%=15,05 \% \\
& \text { Tahun } 2017=\frac{162.753 .166}{1.023 .009 .939} \times 100 \%=15,90 \% \\
& \text { Tahun } 2018=\frac{149.922 .156}{1.047 .566 .568} \times 100 \%=14,31 \%
\end{aligned}
$$

Tabel Perhitungan Rasio Pinjaman Yang Diberikan Terhadap Dana Yang Diterima Di KUD Maju Bersama Pada Tahun 2016-2018

\begin{tabular}{|c|c|c|c|}
\hline Tahun & $\begin{array}{c}\text { Pinjaman Yang } \\
\text { Diberikan }\end{array}$ & $\begin{array}{c}\text { Dana yang } \\
\text { Diterima }\end{array}$ & Rasio(\%) \\
\hline 2016 & 137.762 .925 & 914.794 .069 & 15,05 \\
\hline 2017 & 162.753 .166 & 1.023 .009 .939 & 15,90 \\
\hline 2018 & 149.922 .156 & 1.047 .566 .568 & 14,31 \\
\hline \multicolumn{4}{|c|}{ Sumber: Lap. Keuangan KUD Maju Bersama tahun 2016-2018 (data diolah) }
\end{tabular}

Setelah besarnya rasio diketahui, langkah selanjutnya yaitu melakukan penskoran sesuai dengan Peraturan Deputi Bidang Pengawasan Kementerian Koperasi dan UKM Nomor 6 tahun 2016. Untuk penskoran rasio pinjaman yang diberikan terhadap dana yang diterima di Koperasi Unit Desa Maju Bersama pada tahun 2016-2018 dapat dilihat dalam tabel berikut:

Skor $=$

Tahun 2016 nilai $25=25 \times 5 \%=1,25$

Tahun 2017 nilai $25=25 \times 5 \%=1,25$

Tahun 2018 nilai $25=25 \times 5 \%=1,25$

Tabel Penskoran Rasio Pinjaman Yang Diberikan Terhadap Dana Yang Diterima Di KUD Maju Bersama Pada Tahun 2016-2018

\begin{tabular}{|c|c|c|c|c|}
\hline Tahun & Rasio (\%) & Nilai & Bobot(\%) & Skor \\
\hline 2016 & 15,05 & 25 & 5 & 1,25 \\
\hline 2017 & 15,90 & 25 & 5 & 1,25 \\
\hline 2018 & 14,31 & 25 & 5 & 1,25 \\
\hline
\end{tabular}

Sumber: Perhitungan Rasio-Rasio Aspek Penilaian Kesehatan Koperasi Unit Desa Maju Bersama tahun 2016-2018

b. Analisis Penetapan Tingkat Kesehatan Koperasi Unit Desa (KUD) Maju Bersama Desa Kencana Mulia Kecamatan Rambang

Setelah dihitung skor dari masing-masing aspek penilaian, langkah selanjutnya yaitu menjumlahkan skor masing-masing aspek penilaian untuk memperoleh skor secara keseluruhan yang akan digunakan untuk menetapkan predikat kesehatan koperasi. Berdasarkan hasil perhitungan skor keseluruhan dari aspek penilaian akan ditetapkan predikat tingkat kesehatan 
kopeasi yang dibagi dalam 4 (empat) golongan yaitu sehat, cukup sehat, dalam pengawasan, dan dalam pengawasan khusus.

Berikut hasil perhitungan skor keseluruhan dari aspek penilaian kesehatan koperasi:

Tabel Perhitungan Skor Keseluruhan Penilaian Tingkat Kesehatan Koperasi Unit Desa Maju Bersama pada tahun 2016-2018

\begin{tabular}{|c|c|c|c|c|c|}
\hline \multirow{2}{*}{ No } & \multirow{2}{*}{ Aspek } & \multicolumn{3}{|c|}{ Tahun } & \multirow{2}{*}{$\begin{array}{c}\text { Rata- } \\
\text { rata }\end{array}$} \\
\hline & & 2016 & 2017 & 2018 & \\
\hline \multirow[t]{4}{*}{1} & Permodalan & 12,00 & 12,00 & 12,00 & 12,00 \\
\hline & $\begin{array}{l}\text { a. Rasio modal sendiri } \\
\text { terhadap total aset }\end{array}$ & 3,00 & 3,00 & 3,00 & 3,00 \\
\hline & $\begin{array}{l}\text { b. Rasio modal sendiri } \\
\text { terhadap pinjaman diberikan } \\
\text { yang berisiko }\end{array}$ & 6,00 & 6,00 & 6,00 & 3,00 \\
\hline & $\begin{array}{l}\text { c. Rasio kecukupan modal } \\
\text { sendiri }\end{array}$ & 3,00 & 3,00 & 3,00 & 3,00 \\
\hline \multirow[t]{5}{*}{2} & Kualitas Aktiva Produktif & 15,25 & 14,25 & 14,25 & 14,58 \\
\hline & $\begin{array}{l}\text { a. Rasio pinjaman pada } \\
\text { anggota terhadap total } \\
\text { volume pinjaman diberikan }\end{array}$ & 10,00 & 10,00 & 10,00 & 10,00 \\
\hline & $\begin{array}{l}\text { b. Rasio risiko pinjaman } \\
\text { bermasalah terhadap } \\
\text { pinjaman yang diberikan }\end{array}$ & 4,00 & 3,00 & 3,00 & 3,33 \\
\hline & $\begin{array}{l}\text { c. Rasio cadangan risiko } \\
\text { terhadap pinjaman } \\
\text { bermasalah }\end{array}$ & 0 & 0 & 0 & 0 \\
\hline & $\begin{array}{l}\text { d. Rasio pinjaman berisiko } \\
\text { terhadap pinjaman yang } \\
\text { diberikan }\end{array}$ & 1,25 & 1,25 & 1,25 & 1,25 \\
\hline \multirow[t]{4}{*}{3} & Efisiensi & 6,00 & 6,00 & 6,00 & 6,00 \\
\hline & $\begin{array}{l}\text { a. Rasio beban operasi } \\
\text { anggota terhadap partisipasi } \\
\text { bruto }\end{array}$ & 4,00 & 4,00 & 4,00 & 4,00 \\
\hline & $\begin{array}{l}\text { b. Rasio beban usaha terhadap } \\
\text { SHU Kotor }\end{array}$ & 1,00 & 1,00 & 1,00 & 1,00 \\
\hline & c. Rasio efisiensi pelayanan & 1,00 & 1,00 & 1,00 & 1,00 \\
\hline \multirow[t]{3}{*}{4} & Likuiditas & 3,75 & 3,75 & 3,75 & 3,75 \\
\hline & $\begin{array}{l}\text { a. Rasio kas dan bank } \\
\text { terhadap kewajiban lancar }\end{array}$ & 2,50 & 2,50 & 2,50 & 2,50 \\
\hline & $\begin{array}{l}\text { b. Rasio pinjaman yang } \\
\text { diberikan terhadap dana } \\
\text { yang diterima. }\end{array}$ & 1,25 & 1,25 & 1,25 & 1,25 \\
\hline \multicolumn{2}{|c|}{ Skor Keseluruhan } & 37 & 35,5 & 35,5 & 36,33 \\
\hline \multicolumn{2}{|c|}{$\begin{array}{l}\text { Predikat Tingkat Kesehatan } \\
\text { Koperasi }\end{array}$} & $\begin{array}{l}\text { Tidak } \\
\text { Sehat }\end{array}$ & $\begin{array}{l}\text { Tidak } \\
\text { Sehat }\end{array}$ & $\begin{array}{l}\text { Tidak } \\
\text { Sehat }\end{array}$ & $\begin{array}{l}\text { Tidak } \\
\text { Sehat }\end{array}$ \\
\hline
\end{tabular}

Sumber: Perhitungan Rasio-Rasio Aspek Penilaian Kesehatan Koperasi Unit Desa Maju Bersama tahun 2016-2018 
Berdasarkan hasil perhitungan diatas dapat pula diketahui tingkat kesehatan koperasi Unit Desa Maju Bersama ditinjau dari masing-masing aspek.Skor yang diperoleh dari masing-masing aspek kemudian dibagi dengan skor maksimal setiap aspek tersebut, dan selanjutnya dikalikan skor maksimal ketujuh aspek yaitu 100. Berikut ini merupakan hasil perhitungan dan predikat kesahatan Unit Desa Maju Bersama tahun 2016-2018 ditinjau dari masing-masing aspek:

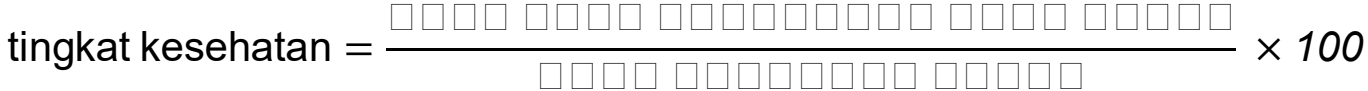

$\begin{array}{lll}\text { Permodalan } & =\frac{12,00}{15,00} \times 100=80 \\ \text { Kualitas Aktiva Produktif } & =\frac{14,58}{25,00} \times 100=58,32 \\ \text { Efisiensi } & =\frac{6,00}{10,00} \times 100=60 \\ \text { Likuiditas } & =\frac{3,75}{15,00} \times 100=25\end{array}$

Predikat kesehatan Koperasi Unit Desa Maju Bersama dinilai dari 4 Aspek yaitu sebagai berikut :

Predikat kesehatan dinilai dari 4 aspek $=\frac{36,33}{65,00} \times 100=55,89$

Tabel Perhitungan dan Predikat Kesehatan Koperasi Unit Desa Maju Bersama tahun 2016-2018

\begin{tabular}{|l|c|c|c|c|}
\hline \multicolumn{1}{|c|}{ Aspek } & $\begin{array}{c}\text { Skor yang } \\
\text { diperoleh (a) }\end{array}$ & $\begin{array}{c}\text { Skor } \\
\text { maksimal (b) }\end{array}$ & $\frac{\mathbf{a}}{\boldsymbol{b}} \times \mathbf{1 0 0}$ & Predikat \\
\hline $\begin{array}{l}\text { Permodalan } \\
\text { Kualitas Aktiva }\end{array}$ & 12,00 & 15,00 & 80 & Sehat \\
\hline Eroduktif & 14,58 & 25,00 & 58,32 & $\begin{array}{c}\text { Kurang } \\
\text { Sehat }\end{array}$ \\
\hline Likuiditas & 6,00 & 10,00 & 60 & $\begin{array}{c}\text { Cukup } \\
\text { Sehat }\end{array}$ \\
\hline \multicolumn{1}{|c|}{ Total } & 3,75 & 15,00 & 25 & $\begin{array}{c}\text { Tidak } \\
\text { Sehat }\end{array}$ \\
\hline
\end{tabular}

Sumber: Perhitungan Skor Keseluruhan Penilaian Kesehatan KUD Maju Bersama tahun 2016-2018

\section{E. PEMBAHASAN}

1. Penilaian aspek kesehatan Koperasi Unit Desa Maju Bersama Desa Kencana Mulia tahun 2016-2018

a) Aspek Permodalan Koperasi Unit Desa Maju Bersama Tahun 2016-2018

Penilaian aspek permodalan Koperasi Unit Desa Maju Bersama dilakukan dengan cara melakukan perhitungan dan penskoran terhadap tiga rasio, diantaranya adalah rasio modal sendiri terhadap total aset, rasio modal sendiri terhadap pinjaman diberikan yang berisiko, dan rasio kecukupan modal sendiri. Adapun penjelasan darihasil perhitungan dan penskoran rasio-rasio dalam aspek permodalan adalah sebagai berikut:

$>$ Rasio Modal Sendiri Terhadap Total Aset 
Berdasarkan analisis yang telah dilakukan dapat diketahui bahwa rasio modal sendiri terhadap total aset pada tahun 2016 menunjukkan hasil sebesar 77,38\%; hal ini berarti setiap Rp 100 total aset yang dimiliki Koperasi Unit Desa Maju Bersama didanai dengan Rp 77,38 modal sendiri yang tersedia. Skor yang diperoleh dari rasio modal sendiri terhadap total aset pada tahun 2016 adalah 3,00.

Pada tahun 2017 rasio modal sendiri terhadap total aset menunjukkan hasil sebesar 74,29\%; hal ini berarti setiap Rp 100 total aset yang dimiliki Koperasi Unit Desa Maju Bersama didanai dengan Rp 74,29 modal sendiri yang tersedia. Skor yang diperoleh dari rasio modal sendiri terhadap total aset pada tahun 2017 adalah 3,00.

Sedangkan Pada tahun 2018 rasio modal sendiri terhadap total aset menunjukkan hasil sebesar 76,40\%; hal ini berarti setiap Rp 100 total aset yang dimiliki Koperasi Unit Desa Maju Bersama didanai dengan Rp 76,40 modal sendiri yang tersedia. Skor yang diperoleh dari rasio modal sendiri terhadap total aset pada tahun 2018 adalah 3,00.

Melihat hasil tersebut dapat diketahui bahwa modal sendiri Koperasi Unit Desa Maju Bersama belum maksimal dalam mendanai total aset yang dimilikinya atau dengan kata lain Koperasi Maju Bersama kekurangan modal sendiri dalam mendanai total aset yang dimilikinya. Dengan demikian, diharapkan Koperasi Unit Desa Maju Bersama dapat meningkatkan jumlah modal sendiri pada tahun-tahun berikutnya. Modal sendiri dapat ditingkatkan dengan cara menambah anggota koperasi sehingga jumlah simpanan pokok dan simpanan wajib akan bertambah, meningkatkan SHU tahun berjalan dan lain sebagainya

Rasio Modal Sendiri Terhadap Pinjaman diberikan yang berisiko

Berdasarkan analisis yang telah dilakukan dapat diketahui bahwa rasio modal sendiri terhadap pinjaman diberikan yang berisiko pada tahun 2016 menunjukkan hasil sebesar 554,03\%; hal ini berarti setiap Rp 100 pinjaman diberikan yang berisiko dijamin dengan $\mathrm{Rp} 554,03$ modal sendiri yang tersedia. Skor yang diperoleh dari rasio modal sendiri terhadap pinjaman diberikan yang berisiko pada tahun 2016 adalah 6,00.

Pada tahun 2017 rasio modal sendiri terhadap pinjaman diberikan yang berisiko menunjukkan hasil sebesar $500,41 \%$ hal ini berarti setiap Rp 100 pinjaman diberikan yang berisiko dijamin dengan $\mathrm{Rp} 500,41$ modal sendiri yang tersedia. Skor yang diperoleh dari rasio modal sendiri terhadap pinjaman diberikan yang berisiko pada tahun 2017 adalah 6,00.

Sedangkan Pada tahun 2018 rasio modal sendiri terhadap pinjaman diberikan yang berisiko menunjukkan hasil sebesar $121,58 \%$ hal ini berarti setiap Rp 100 pinjaman diberikan yang berisiko dijamin dengan Rp 121,58 modal sendiri yang tersedia. Skor yang diperoleh dari rasio modal sendiri terhadap pinjaman diberikan yang berisiko pada tahun 2018 adalah 6,00.

Melihat hasil tersebut dapat diketahui bahwa modal sendiri Koperasi Unit Desa Maju Bersama memiliki kualitas yang baik dalam menutup risiko atas pemberian pinjaman yang tidak didukung dengan agunan yang memadai. Dengan demikian, diharapkan Koperasi Unit Desa Maju Bersama dapat meningkatkan jumlah modal sendiri pada tahun-tahun berikutnya dan meminimalisir pinjaman diberikan yang berisiko dengan 
cara memperhitungkan jaminan yang memadai atas pinjaman yang diberikan.

\section{Rasio Kecukupan Modal sendiri}

Berdasarkan analisis yang telah dilakukan dapat diketahui bahwa rasio kecukupan modal sendiri pada tahun 2016 menunjukkan hasil sebesar 252,10\% hal ini berarti setiap Rp 100 penurunan aset yang dimiliki Koperasi Unit Desa Maju Bersama dijamin dengan Rp 252,10 modal sendiri tertimbang yang tersedia. Skor yang diperoleh dari rasio kecukupan modal sendiri pada tahun 2016 adalah 3,00.

Pada tahun 2017 rasio kecukupan modal sendiri menunjukkan hasil sebesar 256,55\% hal ini berarti setiap Rp 100 penurunan aset yang dimiliki Koperasi Unit Desa Maju Bersama dijamin dengan Rp 256,55 modal sendiri tertimbang yang tersedia. Skor yang diperoleh dari rasio kecukupan modal sendiri pada tahun 2017 adalah 3,00.

Sedangkan Pada tahun 2018 rasio kecukupan modal sendiri menunjukkan hasil sebesar $181,19 \%$ hal ini berarti setiap Rp 100 penurunan aset yang dimiliki Koperasi Unit Desa Maju Bersama dijamin dengan Rp 181,19 modal sendiri tertimbang yang tersedia. Skor yang diperoleh dari rasio kecukupan modal sendiri pada tahun 2018 adalah 3,00 .

Melihat hasil tersebut dapat diketahui bahwa modal sendiri tertimbang Koperasi Unit Desa Maju Bersama memliki kualitas baik dalam menyerap kerugian akibat penurunan aset yang dimilikinya.Dengan demikian, diharapkan Koperasi Unit Desa Maju Bersama meningkatkan kualitas modal sendiri tertimbang untuk menyerap kerugian akibat penurunan aset yang dimilikinya.

b) Aspek Kualitas Aktiva Produktif Koperasi Unit Desa Maju Bersama Tahun 20162018

Penilaian aspek kualitas aktiva produktif Koperasi Unit Desa Maju Bersama dilakukan dengan cara melakukan perhitungan dan penskoran terhadap empat rasio, diantaranya adalah rasio volume pinjaman pada anggota terhadap volume pinjaman yang diberikan, rasio risiko pinjaman bermasalah terhadap pinjaman yang diberikan, rasio cadangan risiko terhadap risiko pinjaman bermasalah, dan rasio pinjaman yang berisiko terhadap pinjaman yang diberikan. Adapun penjelasan hasil perhitungan dan penskoran rasio-rasio dalam aspek kualitas aktiva produktif adalah sebagai berikut:

1) Rasio Pinjaman Pada Anggota Terhadap Total Volume Pinjaman Diberikan

Berdasarkan analisis yang telah dilakukan dapat diketahui bahwa rasio volume pinjaman pada anggota terhadap volume pinjaman diberikan pada tahun 2016 menunjukkan hasil sebesar 88,57\% hal ini berarti dari Rp. 100 volume pinjaman yang diberikan Koperasi Unit Desa Maju Bersama sebanyak Rp. 88,57 pinjaman diberikan pada anggotanya . Skor yang diperoleh dari rasio volume pinjaman pada anggota terhadap volume pinjaman diberikan pada tahun 2016 adalah 10,00.

Pada tahun 2017 rasio volume menunjukkan hasil sebesar 84,96\% hal ini berarti dari Rp. 100 volume pinjaman yang diberikan Koperasi Unit 
Desa Maju Bersama sebanyak Rp. 84,96 pinjaman diberikan pada anggotanya . Skor yang diperoleh dari rasio volume pinjaman pada anggota terhadap volume pinjaman diberikan pada tahun 2017 adalah 10,00 .

Sedangkan pada tahun 2018 rasio volume menunjukkan hasil sebesar 93,07\% hal ini berarti dari Rp. 100 volume pinjaman yang diberikan Koperasi Unit Desa Maju Bersama sebanyak Rp. 93,07 pinjaman diberikan pada anggotanya. Skor yang diperoleh dari rasio volume pinjaman pada anggota terhadap volume pinjaman diberikan pada tahun 2018 adalah 10,00.

Melihat hasil tersebut dapat diketahui bahwa Koperasi Unit Desa Maju Bersama sangat baik dalam memenuhi seluruh pinjaman kepada anggota dan nonanggota koperasi.Hal ini dikarenakan pinjaman yang diberikan Koperasi Unit Desa Maju Bersama tidak hanya berstatus pinjaman anggota tetapi juga pinjaman nonanggota.Dengan demikin, diharapkan Koperasi Unit Desa Maju Bersama dapat mempertahankan bahkan meningkatkan tingginya kegiatan simpan pinjam kepada anggotanya.

2) Rasio Risiko Pinjaman Bermasalah Terhadap Pinjaman Yang Diberikan

Berdasarkan analisis yang telah dilakukan dapat diketahui bahwa rasio risiko pinjaman bermasalah terhadap pinjaman yang diberikan pada tahun 2016 menunjukkan hasil sebesar 14,80\% hal ini berarti setiap Rp 100 pinjaman yang diberikan Koperasi Unit Desa Maju Bersama hanya teradapat Rp 14,80 merupakan pinjaman yang bermasalah. Skor yang diperoleh dari rasio risiko pinjaman bermasalah terhadap pinjaman yang diberikan pada tahun 2016 adalah 4,00.

Pada tahun 2017 rasio risiko pinjaman bermasalah terhadap pinjaman yang diberikan menunjukkan hasil sebesar $15,85 \%$ hal ini berarti setiap Rp 100 pinjaman yang diberikan Koperasi Unit Desa Maju Bersama hanya teradapat Rp 15,85 merupakan pinjaman yang bermasalah. Skor yang diperoleh dari rasio risiko pinjaman bermasalah terhadap pinjaman yang diberikan pada tahun 2017 adalah 3,00.

Sedangkan pada tahun 2018 rasio risiko pinjaman bermasalah terhadap pinjaman yang diberikan menunjukkan hasil sebesar $20,81 \%$ hal ini berarti setiap Rp 100 pinjaman yang diberikan Koperasi Unit Desa Maju Bersama hanya teradapat Rp 20,81 merupakan pinjaman yang bermasalah. Skor yang diperoleh dari rasio risiko pinjaman bermasalah terhadap pinjaman yang diberikan pada tahun 2018 adalah 3,00.

Melihat hasil tersebut dapat diketahui bahwa Koperasi Unit Desa Maju Bersama memiliki tingkat risiko pinjaman bermasalah yang cukup tinggi dari semua pinjam yang diberikan.Dengan demikian, diharapkan Koperasi Unit Desa Maju Bersama membuat peraturan yang tegas agar risiko kerugian atas pinjaman bermasalah dapat diminimalisir.

3) Rasio Cadangan Risiko Terhadap Risiko Pinjaman Bermasalah

Berdasarkan analisis yang telah dilakukan dapat diketahui bahwa rasio cadangan risiko terhadap pinjaman bermasalah pada tahun 2016 menunjukkan hasil sebesar 0\%; hal ini berarti KUD Maju Bersama tidak mempunyai cadangan risiko yang tersedia dalam menutup kerugian atas 
pinjaman yang bermasalah. Skor yang diperoleh dari rasio cadangan risiko terhadap pinjaman bermasalah pada tahun 2016 adalah 0.

Pada tahun 2017 rasio cadangan risiko terhadap pinjaman bermasalah menunjukkan hasil sebesar $0 \%$ hal ini berarti Koperasi Unit Desa Maju Bersama tidak mempunyai cadangan risiko yang tersedia dalam menutup kerugian atas pinjaman yang bermasalah.Skor yang diperoleh dari rasio cadangan risiko terhadap pinjaman bermasalah pada tahun 2017 adalah 0.

Sedangkan pada tahun 2018 rasio cadangan risiko terhadap pinjaman bermasalah menunjukkan hasil sebesar $0 \%$ hal ini berarti Koperasi Unit Desa Maju Bersama tidak mempunyai cadangan risiko yang tersedia dalam menutup kerugian atas pinjaman yang bermasalah.Skor yang diperoleh dari rasio cadangan risiko terhadap pinjaman bermasalah pada tahun 2018 adalah 0.

Melihat hasil tersebut dapat diketahui bahwa Koperasi Unit Desa Maju Bersama tidak memiliki cadangan risiko dalam menutup kerugian atas pinjaman yang bermasalah. Dengan demikian, diharapkan Koperasi Unit Desa Maju Bersama membentuk dana alokasi cadangan risiko dalam menutup risiko kerugian apabila terjadi pinjaman macet atau tidak tertagih.

4) Rasio Pinjaman Berisiko Terhadap Pinjaman Yang Diberikan

Berdasarkan analisis yang telah dilakukan dapat diketahui bahwa rasio pinjaman yang berisiko terhadap pinjaman yang diberikan pada tahun 2016 menunjukkan hasil sebesar 100\% hal ini berarti total pinjaman yang diberikan KUD Maju Bersama semuanya tidak didukung agunan yang memadai. Skor yang diperoleh dari rasio pinjaman yang berisiko terhadap pinjaman yang diberikan pada tahun 2016 adalah 1,25.

Pada tahun 2017 rasio pinjaman yang berisiko terhadap pinjaman yang diberikan menunjukkan hasil sebesar 100\%; hal ini berarti total pinjaman yang diberikan Koperasi Unit Desa Maju Bersama semuanya tidak didukung agunan yang memadai. Skor yang diperoleh dari rasio pinjaman yang berisiko terhadap pinjaman yang diberikan pada tahun 2017 adalah 1,25.

Sedangkan pada tahun 2018 rasio pinjaman yang berisiko terhadap pinjaman yang diberikan menunjukkan hasil sebesar $100 \%$ hal ini berarti total pinjaman yang diberikan Koperasi Unit Desa Maju Bersama semuanya tidak didukung agunan yang memadai. Skor yang diperoleh dari rasio pinjaman yang berisiko terhadap pinjaman yang diberikan pada tahun 2018 adalah 1,25.

Melihat hasil tersebut dapat diketahui bahwa total pinjaman yang diberikan Koperasi Unit Desa Maju Bersama semuanya tidak didukung dengan agunan yang memadai. Dengan demikian, diharapkan Koperasi Maju Bersama dapat memperkecil pinjaman berisiko dengan cara memperhitungkan jaminan yang digunakan dalam pemberian pinjaman.

c) Aspek Efisiensi Koperasi Maju Bersama Tahun 2016-2018

Penilaian aspek efisiensi Koperasi Unit Desa Maju Bersama dilakukan dengan cara melakukan perhitungan dan penskoran terhadap tiga rasio, diantaranya adalah rasio biaya operasional pelayanan terhadap partispasi bruto, rasio beban usaha terhadap SHU kotor, dan rasio efisiensi pelayanan. 
Adapun penjelasan hasil perhitungan dan penskoran rasio-rasio dalam aspek efisiensi adalah sebagai berikut:

Rasio Beban Operasi Anggota Terhadap Partisipasi Bruto

Berdasarkan analisis yang dilakukan dapat diketahui bahwa rasio beban operasi anggota terhadap partisipasi bruto pada tahun 2016 menunjukkan hasil sebesar 13,23\% hal ini berarti setiap Rp100 partisipasi bruto yang diperoleh KUD Maju Bersama mengelurkan beban operasi anggota sebesar $\mathrm{Rp} \mathrm{13,23.} \mathrm{Skor} \mathrm{yang} \mathrm{diperoleh} \mathrm{dari} \mathrm{rasio} \mathrm{beban} \mathrm{operasi}$ anggota terhadap partisipasi bruto pada tahun 2016 adalah 4,00.

Pada tahun 2017 rasio eban operasi anggota terhadap partisipasi bruto menunjukkan hasil sebesar $16,33 \%$ hal ini berarti setiap Rp 100 partisipasi bruto yang diperoleh Koperasi Unit Desa Maju Bersama mengelurkan beban operasi anggota sebesar Rp 16,33. Skor yang diperoleh dari rasio beban operasi anggota terhadap partisipasi bruto pada tahun 2017 adalah 4,00.

Sedangkan pada tahun 2018 rasio eban operasi anggota terhadap partisipasi bruto menunjukkan hasil sebesar 18,53\% hal ini berarti setiap Rp 100 partisipasi bruto yang diperoleh Koperasi Unit Desa Maju Bersama mengelurkan beban operasi anggota sebesar Rp 18,53. Skor yang diperoleh dari rasio beban operasi anggota terhadap partisipasi bruto pada tahun 2018 adalah 4,00.

Melihat hasil tersebut dapat diketahui bahwa Koperasi Maju Bersama dalam memperoleh jumlah partisipasi bruto mengeluarkan beban yang terbilang tinggi, sehingga pendapatan yang dihasilkan Koperasi Unit Desa Maju Bersama belum maksimal.Dengan demikian, diharapkan KUD Maju Bersama dapat mengurangi pengeluran beban operasi anggota.

\section{Rasio Beban Usaha Terhadap SHU Kotor}

Berdasarkan analisis yang telah dilakukan dapat diketahui bahwa rasio beban usaha terhadap SHU kotor pada tahun 2016 menunjukkan hasil sebesar 235,03\% hal ini berarti setiap Rp 100 SHU kotor yang diperoleh Koperasi Unit Desa Maju Bersama mengelurkan beban usaha sebesar Rp 235,03. Skor yang diperoleh dari rasio beban usaha terhadap SHU kotor pada tahun 2015 adalah 1,00.

Pada tahun 2017 rasio beban usaha terhadap SHU kotor menunjukkan hasil sebesar 236,676\%; hal ini berarti setiap Rp 100 SHU kotor yang diperoleh, Koperasi Unit Desa Maju Bersama mengelurkan beban usaha sebesar $\mathrm{Rp}$ 236,67. Skor yang diperoleh dari rasio beban usaha terhadap SHU kotor pada tahun 2017 adalah 1,00.

Sedangkan pada tahun 2018 rasio beban usaha terhadap SHU kotor menunjukkan hasil sebesar 430,44\%; hal ini berarti setiap Rp 100 SHU kotor yang diperoleh, Koperasi Unit Desa Maju Bersama mengelurkan beban usaha sebesar Rp 430,44. Skor yang diperoleh dari rasio beban usaha terhadap SHU kotor pada tahun 2018 adalah 1,00.

Melihat hasil tersebut dapat diketahui bahwa Koperasi Unit Desa Maju Bersama dalam hal memperoleh SHU kotor tergolong sangat tidak baik dengan beban usaha yang dikeluarkan terbilang terlalu tinggi.Dengan demikian, diharapkan KUD Maju Bersama mengurangi beban usaha yang dikeluarkannya agar SHU kotor yang diperoleh bisa maksimal. 


\section{Rasio Efisiensi Pelayanan}

Berdasarkan analisis yang telah dilakukan dapat diketahui bahwa rasio efisiensi pelayanan pada tahun 2016 menunjukkan hasil sebesar $58,21 \%$ hal ini berarti setiap $\mathrm{Rp} 100$ total volume pinjaman yang diberikan Koperasi Unit Desa Maju Bersama membiayai beban karyawan sebesar $\mathrm{Rp} 58,21$. Skor yang diperoleh dari rasio efisiensi pelayanan pada tahun 2016 adalah 2,00.

Pada tahun 2017 rasio efisiensi pelayanan menunjukkan hasil sebesar $50,69 \%$ hal ini berarti setiap Rp 100 total volume pinjaman yang diberikan Koperasi Unit Desa Maju Bersama membiayai beban karyawan sebesar Rp 50,69. Skor yang diperoleh dari rasio efisiensi pelayanan pada tahun 2017 adalah 2,00.

Sedangkan pada tahun 2018 rasio efisiensi pelayanan menunjukkan hasil sebesar $58,39 \%$ hal ini berarti setiap Rp 100 total volume pinjaman yang diberikan Koperasi Unit Desa Maju Bersama membiayai beban karyawan sebesar $\mathrm{Rp} 58,39$. Skor yang diperoleh dari rasio efisiensi pelayanan pada tahun 2018 adalah 2,00.

Melihat hasil tersebut dapat diketahu bahwa Koperasi Unit Desa Maju Bersama dalam menjalankan usaha simpan pinjam tergolong kurang baik karena setiap pinjaman yang diberikan Koperasi Maju Bersama mengeluarkan biaya karyawan yang sedikit tinggi.Dengan demikian, diharapkan Koperasi Maju Bersama dapat meningkatkan usaha simpan pinjamnya untuk meringankan beban karyawan tahun-tahun berikutnya.

d) Aspek Likuiditas Koperasi Unit Desa Maju Bersama Tahun 2016-2018

Penilaian aspek likuiditas Koperasi Unit Desa Maju Bersama dilakukan dengan cara melakukan perhitungan dan penskoran terhadap dua rasio,diantaranya adalah rasio kas dan bank terhadap kewajiban lancar dan rasio pinjaman yang diberikan terhadap dana yang diterima. Adapun penjelasan hasil perhitungan dan penskoran rasio-rasio dalam aspek likuiditas adalah sebagai berikut:

1) Rasio Kas Dan Bank Terhadap Kewajiban Lancar

Berdasarkan analisis yang telah dilakukan dapat diketahui bahwa rasio kas dan bank terhadap kewajiban lancar pada tahun 2016 menunjukkan hasil sebesar 104,40\%, hal ini berarti setiap Rp 100 kewajiban lancar dijamin dengan Rp 104,40 kas dan bank yang tersedia. Skor yang diperoleh dari rasio kas dan bank terhadap kewajiban lancar pada tahun 2016 adalah 2,50.

Pada tahun 2017 rasio kas dan bank terhadap kewajiban lancar menunjukkan hasil sebesar $73,82 \%$, hal ini berarti setiap Rp 100 kewajiban lancar dijamin dengan Rp 73,82 kas dan bank yang tersedia. Skor yang diperoleh dari rasio kas dan bank terhadap kewajiban lancar pada tahun 2017 adalah 2,50.

Sedangkan pada tahun 2018 rasio kas dan bank terhadap kewajiban lancar menunjukkan hasil sebesar $81,35 \%$, hal ini berarti setiap Rp 100 kewajiban lancar dijamin dengan Rp 81,35 kas dan bank yang tersedia. Skor yang diperoleh dari rasio kas dan bank terhadap kewajiban lancar pada tahun 2018 adalah 2,50. 
Melihat hasil tersebut dapat diketahui bahwa rasio kas dan bank terhadap kewajiban lancarnya di Koperasi Maju Bersama hasilnya tinggi.Akan tetapi, tingginya rasio ini tidak menjamin bahwa koperasi tersebut dapat memenuhi kewajiban jangka pendeknya dengan menggunakan kas dan bank yang dimilikinya.Rasio yang tinggi menunjukkan adanya kas dan bank yang berlebihan dibanding dengan tingkat kebutuhannya. Rasio yang tinggi tersebut memang baik dari sudut pandang kreditur, tetapi dari sudut debitur kurang menguntungkan karena aktiva lancar dalam hal ini kas dan bank tidak didaya gunakan secara efektif dalam pengembangan usahanya, sehingga banyak dana yang menganggur. Oleh sebab itu, keuntungan yang diperoleh Koperasi Unit Desa Maju Bersama sangatlah kecil sehingga tidak mampu dalam membayar kewajiban jangka pendeknya atau sering disebut over likuid.Dengan demikian, diharapkan Koperasi Unit Desa Maju Bersama dapat memperkecil saldo kas dan bank sesuai dengan kebutuhannya. Saldo kas dan bank ini dapat diperkecil dengan cara menyalurkan dana tersebut ke nasabah dalam bentuk pinjaman.

2) Rasio Pinjaman Yang Diberikan Terhadap Dana Yang Diterima

Berdasarkan analisis yang telah dilakukan dapat diketahui bahwa rasio pinjaman yang diberikan terhadap dana yang diterima pada tahun 2016 menunjukkan hasil sebesar 15,05\%; hal ini berarti setiap Rp 100 dana yang diterima Koperasi Unit Desa Maju Bersama menjamin total pinjaman yang diberikan sebesar Rp 15,05. Skor yang diperoleh dari rasio pinjaman pinjaman yang diberikan terhadap dana yang diterima pada tahun 2016 adalah 1.25.

Pada tahun 2017 rasio pinjaman yang diberikan terhadap dana yang diterima menunjukkan hasil sebesar 15,90\%; hal ini berarti setiap Rp 100 dana yang diterima Koperasi Unit Desa Maju Bersama menjamin total pinjaman yang diberikan sebesar Rp 15,90. Skor yang diperoleh dari rasio pinjaman pinjaman yang diberikan terhadap dana yang diterima pada tahun 2017 adalah 1,25.

Sedangkan pada tahun 2018 rasio pinjaman yang diberikan terhadap dana yang diterima menunjukkan hasil sebesar 14,31\%; hal ini berarti setiap Rp 100 dana yang diterima Koperasi Unit Desa Maju Bersama menjamin total pinjaman yang diberikan sebesar Rp 14,31. Skor yang diperoleh dari rasio pinjaman pinjaman yang diberikan terhadap dana yang diterima pada tahun 2018 adalah 1,25.

Melihat hasil tersebut dapat diketahui bahwa Koperasi Unit Desa Maju Bersama dalam memberikan pinjamannya dengan menggunakan dana yang diterima belum maksimal, hal ini dikarenakan masih banyak dana yang menganggur atau dengan kata lain Koperasi Unit Desa Maju Bersama belum maksimal dalam menggunakan dana yang diterima dalam menjalankan usahanya. Dengan demikian, diharapkan Koperasi Unit Desa Maju Bersama lebih memaksimalkan lagi pemanfaatan dana yang diterimanya dalam mengembangkan usahanya. 


\section{Penetapan tingkat kesehatan Koperasi Unit Desa Maju Bersama Desa Kencana Mulia Tahun 2016-2018}

Tingkat kesehatan unit simpan pinjam Koperasi Unit Desa Maju Bersama dinilaiberdasarkan tujuh aspek yang sudah ditetapkan pada Peraturan Deputi Bidang Pengawasan Kementerian Koperasi dan UKM Nomor 06/Per/Dep.6/IV/2016 tentang pedoman penilaian kesehatan koperasi simpan pinjam dan unit simpan pinjam koperasi. Dimana peneliti hanya melakukan peniilaian dari empat aspek, diantaranya adalah permodalan, kualitas aktiva produktif, efisiensi, dan likuiditas.

Dari hasil perhitungan keempat aspek yang telah dilakukan di Koperasi Unit Desa Maju Bersama desa Kencana Mulia, tingkat kesehatan Koperasi Unit Desa Maju Bersama pada tahun 2016 memperoleh skor 37 dengan predikat koperasi tidak sehat, pada tahun 2017 memperoleh skor 35,5 dengan predikat tidak sehat dan pada tahun 2018 memperoleh skor 35,5 dengan predikat tidak sehat. Skor rata-rata yang diperoleh Koperasi Unit Desa Maju Bersama dari tahun 2016-2018 yaitu 36,33 dapat dikategorikan tidak sehat. Dengan demikian dapat dikatakan bahwa tingkat kesehatan Koperasi Unit Desa Maju Bersama dari tahun 2016-2018 mendapat predikat tidak sehat dengan total skor 36,33.

Berdasarkan hasil perhitungan skor keseluruhan aspek penilaian kesehatan koperasi, dapat pula diketahui tingkat kesehatan Koperasi Unit Desa Maju Bersama ditinjau dari masing-masing aspek.Skor yang diperoleh dari masing-masing aspek kemudian dibagi dengan skor maksimal setiap aspek tersebut, dan selanjutnya dikalikan skor maksimal ketujuh aspek yaitu 100. Adapun penjelasan predikat kesehatan Koperasi Unit Desa Maju Bersama tahun 2016-2018 ditinjau dari masingmasing aspek adalah sebagai berikut:

\section{* Permodalan}

Berdasarkan hasil perhitungan dan predikat kesahatan Koperasi Unit Desa Maju Bersama tahun 2016-2018, aspek permodalan mendapatkan skor 80,00. Skor tersebut berada pada kisaran 80-100, sehingga dapat dikategorikan dengan predikat sehat. Artinya, permodalan yang dimiliki Koperasi Unit Desa Maju Bersama dapat dikatakan baik dalam mendukung kegiatan operasionalnya dan mampu menyerap kerugian atas penurunan aset yang dimilikinya. Akan tetapi, hasil yang diperoleh tersebut belum maksimal karena Koperasi Unit Desa Maju Bersama masih kekurangan modal sendiri dalam mendanai aset yang dimilikinya.

Kualitas Aktiva Produktif

Berdasarkan hasil perhitungan dan predikat kesahatan Koperasi Unit Desa Maju Bersama tahun 2016-2018, aspek kualitas aktiva produktif mendapatkan skor 58,32. Skor tersebut berada pada kisaran 40-60, sehingga dapat dikategorikan dengan predikat kurang sehat.Artinya, aktiva yang dimiliki Koperasi Unit Desa Maju Bersama belum mencapai tingkat penghasilan yang diharapkan.

\section{Efisiensi}

Berdasarkan hasil perhitungan dan predikat kesahatan Koperasi Unit Desa Maju Bersama tahun 2016-2018, aspek efisiensi mendapatkan skor 60,00. Skor tersebut berada pada kisaran 60-80, sehingga dapat dikategorikan dengan predikat cukup sehat.Hal ini berarti bahwa dalam perihal efisiensi, Koperasi Unit Desa Maju Bersama mampu mengendalikan pengeluran biaya operasionalnya.

Likuiditas

Berdasarkan hasil perhitungan dan predikat kesahatan Koperasi Unit Desa Maju Bersama tahun 2016-2018, aspek likuiditas mendapatkan skor 25. Skor 
tersebut berada pada kisaran 20-40, sehingga dapat dikategorikan dengan predikat tidak sehat. Hal ini berarti bahwa Koperasi Unit Desa Maju Bersama dalam mengelola aset yang dimiliki untuk memenuhi kewajiban jangka pendeknya tergolong buruk karena terdapat kas dan bank yang berlebihan yang berakibat banyaknya dana yang menganggur yang didayagunakan secara efektif dalam mengembangkan usahanya. Oleh sebab itu, keuntungan yang diperoleh Koperasi Unit Desa Maju Bersama sangatlah kecil sehingga tidak mampu dalam membayar kewajiban jangka pendeknya.

\section{F. KESIMPULAN DAN SARAN}

1) Kesimpulan

Berdasarkan analisis data yang dilakukan berkaitan dengan tingkat kesehatan Koperasi Unit Desa Maju Bersama, maka dapat diambil kesimpulan bahwa:.

a. Ditinjau dari aspek permodalan Koperasi Unit Desa Maju Bersama tahun 20162018 memperoleh skor 80,00 skor tersebut berada pada kisaran 80-100, sehingga dapat dikategorikan dengan predikat sehat.

b. Ditinjau dari aspek kualitas aktiva produktif Koperasi Unit Desa Maju Bersama tahun 2016-2018 memperoleh skor 58,32 skor tersebut berada pada kisaran 40-60, sehingga dapat dikategorikan dengan predikat kurang sehat.

c. Ditinjau dari aspek efisiensi Koperasi Unit Desa Maju Bersama tahun 20162018 memperoleh skor 60 skor tersebut berada pada kisaran 60-80, sehingga dapat dikategorikan dengan predikat cukup sehat.

d. Ditinjau dari askpek likuiditas Koperasi Unit Desa Maju Bersama tahun 20162018 memperoleh skor 25 skor tersebut berada kisaran 20-40, sehingga dapat dikategorikan dengan predikat tidak sehat.

e. Tingkat kesehatan Koperasi Unit Desa Maju Bersama tahun 2016-2018 secara keseluruhan dari ke empat aspek tersebut berada dalam kategori kurang sehat dengan mendapatkan skor rata-rata 55,89

\section{2) Saran}

Berdasarkan kesimpulan yang telah dijabarkan dari analisis data mengenai tingkat kesehatan Koperasi Unit Desa Maju Bersama pada tahun 2016-2018, maka saran yang dapat disampaikan adalah sebagai berikut:

a. Dalam hal aspek permodalan, sebaiknya pihak pengelola koperasi Koperasi Unit Desa Maju Bersama semakin mempertinggi perolehan kualitas modal sendiri dan mempertahankan perolehan modal tertimbang dan aktiva tertimbangnya. Modal sendiri dapat ditingkatkan dengan cara menarik lebih banyak orang agar bergabung menjadi anggota koperasi.

b. Dalam hal aspek kualitas aktiva produktif, sebaiknya pengelola Koperasi Unit Desa Maju Bersama perlu membuat peraturan yang lebih tegas dan persyaratan yang lebih ketat ketika nasabah mengajukan pinjaman harus disesuaikan dengan agunan yang memadai. Hal ini diperlukan untuk memperkecil pinjaman berisiko dan meminimalisir risiko kerugian. Hendaknya Koperasi Unit Desa Maju Bersama membentuk dana alokasi cadangan risiko, karena hal ini sangat penting untuk menutup risiko apabila terjadi pinjaman macet atau tidak tertagih.

c. Dalam hal aspek likuiditas, diharapkan pengelola Koperasi Unit Desa Maju Bersama dapat memperkecil jumlah kas dan bank dimiliki dengan cara menyalurkan dana tersebut ke nasabah dalam bentuk pinjaman, sehingga 
dapat mengembangkan usahanya dan nantinya bisa memperbesar keuntungan yang diperolehnya. Keuntungan yang besar ini nantinya dapat digunakan untuk membayar kewajiban lancarnya.

\section{DAFTAR PUSTAKA}

Baswir, Revrisond. (2010). Koperasi Indonesia.Yogyakarta:BPFE.

Eindrias, T.D \& Azizah, D.F(2016). Analisis Tingkat Kesehatan Koperasi Simpan Pinjam Berdasarkan Peraturan Nomor: 06/Per/Dep.6/IV/2016 (Studi Kasus Pada Koperasi Simpan Pinjam Bahagia Kediri; Jurnal Administrasi Bisnis Vol. 51 No.2 (2017) 135-140. Universitas Brawijaya..

Syaifudin, M.I. (2017). Analisis Tingkat Kesehatan Koperasi Simpan Pinjam di Kabupaten Rembang Tahun 2014-2015.Yogyakarta.Skripsi.Universitas Negeri Yogyakarta.

Peraturan Deputi Bidang Pengawasan Kementrian Koperasi dan Usaha Kecil dan Menengah No.06/Per/Dep.6/IV/2016 tentang Pedoman Penilaian Koperasi Simpan Pinjam dan Unit Simpan Pinjam Koperasi.

Peraturan Pemerintah Republik Indonesia Nomor 9 Tahun 1995 tentang Pelaksanaan Kegiatan Usaha Simpan Pinjam Oleh Koperasi.

Rudianto. (2010). Akuntansi Koperasi,Erlangga: PT Gelora Aksara Pratama.

Subandi.(2013). Ekonomi Koperasi (Teori dan Praktik). Bandung: Alfabet.

Sugiyono, 2016, Metode Penelitian Kuantitatif, Kualitatif, dan Kombinasi (Mixed Metods),. Bandung: Alfabeta CV.

Tanjung, M. Azrul. (2016). Koperasi Dan UMKM Sebagai Fondasi Perekonomian Indonesia. Jakarta: Erlangga.

Undang-Undang Republik Indonesia Nomor 25 Tahun 1992 tentang Perkoperasian, penerbit ARKOLA, Surabaya.

Wijayanti, Asih. (2012). Evaluasi Kinerja Koperasi Simpan Pinjam di Kabupaten Kulonprogo Tahun 2009-2010.Skripsi.Pendidikan Ekonomi Fakultas Ekonomi Universitas Negeri Yogyakarta. 